\title{
Knowledge from Experience: The Rise of Empiricism
}

A central foundation of the self-image and self-representation of sixteenth-century physicians continued to be their profound knowledge of the works of both ancient and - increasingly - more recent medical authorities. Even in Padua, Bologna, and Montpellier, where practical training had a particularly prominent place, the curriculum was devoted above all to reading and commenting on the Galenic and Hippocratic texts and on Avicenna's Canon medicinae. Numerous later entries in Handsch's notebooks illustrate that physicians in their everyday practice consistently took recourse to these writings when dealing with diagnostic, prognostic, and therapeutic questions, and treated them as the definitive authority when an issue was under dispute. Handsch's notes show that a physician could be expected to know numerous passages by rote, even on very specific issues, and to put them to good use at the sickbed. They prided themselves of their detailed knowledge of the authoritative texts and sought to surpass each other. At one point, Handsch lost a jug of wine because he was not prepared to believe that, according to the Hippocratic aphorisms, melancholy and frenzy tended to occur in the springtime, in spite of the fact that spring was considered an especially healthy time of year. ${ }^{1}$

Beginning in the late fifteenth century, however, the authoritative books were increasingly accompanied by another book: the "book of nature". Empirical approaches acquired greater significance. ${ }^{2}$ In the history of science and the history of medicine, the esteem for empirical knowledge that burgeoned during this period has been thoroughly researched and appreciated with respect to anatomy and botany above all. Coming from anatomy, "autopsia”, or seeing for oneself, became a central epistemological ideal. In botany, a major reason for relying on empirical knowledge came from the fact that the new, exotic plants from Asia and America and even many plants from central and northern Europa did not find mention in the works of the ancient authorities. Public controversies about who could claim to be the first who discovered or describeed a new anatomical structure or a new plant became a common phenomenon.

By contrast, historians have devoted far less attention to the role of practical medicine in the rise of empirical approaches than it deserves. I would argue that medical practice was at least as important as a major driving force behind this development. Admittedly, in hindsight, unlike with anatomy and botany -

1 Cod. 11207, fol. 181v; cf. book 3, aph. 20, in Hippocrates, Aphorismi (1538), p. 127.

2 Very useful overview in Wear, Medicine (1995).

Ә Open Access. (c) 2022 Michael Stolberg, published by De Gruyter. (c))BY-NC-ND This work is licensed under the Creative Commons Attribution-NonCommercial-NoDerivatives 4.0 International License. https://doi.org/10.1515/9783110733549-013 
and this is certainly the principal reason for the meager historical attention there were hardly any new discoveries in practical medicine at the time which are today thought to still hold water in medicine. ${ }^{3}$ Such a retrospective judgement, however, does not come close to doing justice to the perception of the physicians of the period. They were convinced that, precise empirical observation at the sickbed would lead to important new insights and would help them to gain an ever firmer grasp on the disease process and to treat patients more successfully. ${ }^{4}$

Several developments impelled medicine in general toward the acquisition of knowledge through observation. Front and center here was the transformation of natural history, which took place over a long period of time and which was also largely responsible for advancing this development in botany and anatomy. Beginning in the late Middle Ages, the "particulars", the knowledge of the individual things of nature, their characteristics and faculties as compared to the "universals", increasingly garnered attention. ${ }^{5}$

Although things might seem otherwise at first glance, medical humanism, too, fostered empirical tendencies in its own way. Historians have often largely reduced medical humanism to a philological endeavor, to the point of declaring the philological work of humanism an end in itself. And, more than anything, they have highlighted the humanist disparagement of the (Latin translations of the) works of Arabic authors. This view does not fully do justice to the motives of the medical humanists, however. The reconstruction of the authentic teachings of ancient authors was not an end in itself. Rather, from the point of view of the humanists, the ancient medical works embodied experience that had proven true and valid over centuries of medical practice. Giving new life to the legacy of ancient medicine in its original form was therefore of great practical interest. The aim was to "practise medicine in the manner of the ancient physicians", as Jerome Bylebyl wrote about Giovanni Battista da Monte, and thus to place medicine on a new foundation. ${ }^{6}$ Some Hippocratic works especially, above all the Aphorisms and the Epidemics, presented themselves to the reader as empirical accounts or at least as collections of individual insights that were gained from experience.

3 See e.g. the somewhat anachronistic assessment by Oberrauch (Oberrauch, Medizin (2012), p. 362) who claims that there were no substantial developments in sixteenth-century medicine, due above all to the slow progress in anatomy.

4 Stolberg, Empiricism (2013).

5 Park, Observations (2011); see also Premuda, Discepolo (1963); for an overview of the later developments see Ben-Chaim, Experimental philosophy (2004).

6 Bylebyl, School of Padua (1979), p. 341. 
And even in Galen, the physicians found case histories here and there. These case histories flagrantly served his self-adulation and were intended to serve as proof of his diagnostic acumen and his superior curative abilities. Nevertheless, they were considered valuable in the sixteenth century, so much so that they were collected and published as a model for modern medical practice. ${ }^{7}$

Furthermore, in medical lay culture experience was valued highly and physicians grew up within this culture, were socialized into it throughout their childhood and youth, before they embarked on their academic studies. Laypeople's use of medicinal herbs and even their trust in healing charms and other magicalsympathetic cures, were founded on experience, on the observation that the sick got better. In early modern vernacular collections of recipes, we regularly find expressions such as "tried and tested" or in Latin "probatum est" at the end of the recipes, sometimes even including the place and time of the successful application. ${ }^{8}$

A last factor, finally, which may well even have contributed decisively to the empirical turn, is more difficult to pin down. Since the fifteenth century, the number of learned physicians began to rise dramatically, and for many of them, medical practice was their principal source of income. And they found that the most important means by far to acquire esteem and authority and attract patients was not bookish learning but successful cures. Physicians made use of numerous remedies whose effects could not be - or could only very indirectly be - traced to the specific mixture of the primary qualities (cold, hot, dry, and wet) and to the secondary qualities derived from these such as "softening" and "purgative". Rather, these remedies were characterized by specific effects on certain complaints and diseases or they at least appeared to be capable of targeting particular humors or types of morbid matter and attracting and voiding them. Such specific faculties could not be explained rationally based on the perception of a dominant cold or wet quality for example. They could only be inferred from the observation of their effects on the patient.

Even Galen, who was very critical of physicians who wanted to base their medicine on experience alone, relied heavily on empirical observation when choosing medications. ${ }^{9}$ As Handsch gleaned from his reading of Galen, "Experience is the most reliable judge of the faculties inherent in medications". ${ }^{10}$ The

7 Champier, Historiales campi (1532).

8 E.g. Staatsbibliothek Berlin, Hdschr. 442, recipe book from the late sixteenth century, on an eye ointment that had proven helpful in Austria and Hungary, in 1575.

9 Debru, Galen (2000), p. 625.

10 Cod. 11239, fol. 29r: "Experientia est certissima iudicatrix facultatum quae medicamentis insunt." 
scholastic physicians of the Middle Ages had accepted this to a degree. Toxic effects, for example, as Handsch learned when reading Pietro d'Abano (1250/ 57-1316), could not always be attributed to a peculiar mixture of primary qualities. Similarly, the successful application of strong antidotes such as St. John's wort (hypericum) and swallowwort (vincetoxicum) could not be explained by the mixture of elementary qualities. It was owed, rather, to their inherent specific faculties or to astral influences. ${ }^{11}$

\section{Empirica, Experimenta, and Secret Remedies}

In the sixteenth century, learned medicine widely recognized the significance of specific faculties of many remedies that could only be apprehended by observing the effects on patients. Knowing the characteristic mixture of primary qualities of each medicinal plant remained indispensable but the specific effects on different diseases were widely ascribed to occult (in the literal sense of hidden), supraelemenary powers. ${ }^{12}$ A well-known example was peony, which had long been appreciated as an effective remedy for epilepsy, among other things. Some animal-derived substances, too, were believed to have a proprietas specifica. Johannes Willenbroch, for example, thought that freshly killed and halved doves, placed on the heads of the mad ("phrenetici"), had a specific effect. ${ }^{13}$ In Padua, Handsch experienced how, after a dissection, his fellow students scrambled to get their hands on the fat of the dissected corpse, which was appreciated for its therapeutic effects. ${ }^{14}$

A second essential element was also at work. Physicians often relied on more than the effect of just one medicinal plant. They used formulas, mixtures of different healing plants which they devised themselves or took from the literature or learned from colleagues. Before even setting up their own practice, medical students eagerly noted down the "tried and tested" remedies their professors shared with them. Many of such recipes can be found in Handsch's student notes. The notes taken by one or several students of Antonio Musa Brasavola, who accompanied his (or their) professors on sick visits in Ferrara, mainly recorded the mixtures of drugs they prescribed. ${ }^{15}$ As a student in Padua, Johannes Brünsterer assembled

11 Cod. 11240, foll. 74r-81r, here fol. 76r and fol. 81r.

12 Richardson, Generation (1985).

13 Cod. 11183, fol. 182v.

14 Cod. 11210, fol. 191v, "scholares raptim abscindebant pinguedinem ad medicationes profuturam."

15 Biblioteca Ariostea, Ferrara, Collezione Antonelli, Ms. 531. 
close to fifteen pages with notes on different mixtures of medications under the heading "Empirica quaedam". 16

The great appreciation physicians had for tried and tested recipes as well as the overarching significance of these recipes in everyday practice is reflected by the extensive collections of experimenta which physicians compiled for their personal use. "Experimenta" must not be misunderstood as "experiments" in the present-day sense. At the time, it was the common term for "tried and tested" or "proven" medicines. Even before he started his medical studies, Handsch as an assistant of Ulrich Lehner in Prague began to collect in an Antidotariolus formulas which he received from Lehner and other physicians or which he found in books. ${ }^{17}$ Included here were secret remedies such as the "electuarium secretum" of a certain Ludovicus, which was to protect against asthma, the "mirabile secretum" of a Mantuan physician named Calderano, and recipes for mixtures of drugs that referred in their names to the physicians or healers who created them, such as an "unguentum magistri Galeacii”, a "confectio magistri Fontani”, and an "electuarium magistri Antonii”. Whole sections of Handsch's notebooks are devoted to the "experimenta et secreta" of a particular physician. As an addition to his notes from his time with Lehner, Handsch would later compile a further substantial volume with experimenta. ${ }^{18}$ When Handsch was treating patients, he drew from his collection of recipes. Again and again, he turned to the experimenta of other physicians, for example to Johann Neefe's laxative syrup. ${ }^{19}$ Handsch even used the plague powder of a certain "Dominus Venceslaus" on himself, and, during the great plague epidemic, he left some for his brother and his brother's family, all of whom, it appeared, remained healthy as a result. ${ }^{20}$

Handsch and the physicians he worked with were not shy either about their use of the collection of "empirical" drugs which Benedetto Vittore published in 1551. ${ }^{21}$ Mattioli praised Vittore's anti-paralysis pills, among other things. ${ }^{22}$ Gallo took Vittore's book with him when he visited a noble patient. ${ }^{23}$ Even the remedies of non-academic healers and laypeople earned the attention of the physicians

16 Universitätsbibliothek, Erlangen, Ms. 911, foll. 307-322.

17 Cod. 11200: "Antidotariolus. Formulae medicamentorum aliquot. Georgius Handschius Lippensis. Pragae 1549.”

18 Cod. 11251: "Experimenta quaedam brevia comparatu facilia vulgaria probata excerpta passim ab authoribus et secretis aliorum medicorum".

19 E.g. Cod. 11183, fol. $275 \mathrm{r}$ and fol. 458v.

20 Cod. 11200, fol. 30r and fol. 31r.

21 E.g. Cod. 11183, fol. 314v, on Dr. Merla; ibid., fol. 479r; Cod. 11207, fol. 89v, on Gallo's praise for Vittore's oil against dropsy; cf. Vittore, Medicatio empirica (1551).

22 Cod. 11183, fol. 479r.

23 Cod. 11207, fol. 224 r. 
if they seemed to prove their worth in practice. One treatment Handsch took note of was administering a decoction of horse manure to combat jaundice. ${ }^{24}$ And he heard from an old farmer that a drink made with boiled hazelwort (asarum) would drive away "das Kalte", that is the "cold" fever. ${ }^{25}$

With the help of their experimenta, physicians stood a chance of achieving superior curative results, which would make them stand out among their peers, allow them to win the trust of wealthy and noble patients, and perhaps even secure them a position as the personal physician to a prince or king. Handsch praised one of the secreta he had noted down, adding that with its help he had "attained glory and money quite a number of times". ${ }^{26}$ For good reasons, any self-respecting physician developed his own specific mixtures of drugs and secret remedies. Gallo, for example, had allegedly saved numerous people from the plague with a secretum. ${ }^{27}$ Tremenus had a secretum, which he often applied to the stomach area. ${ }^{28}$ According to Handsch, the unguentum mirabile, which Mattioli "invented" ("ex inventione [. . .] Mattheoli”) quickly healed all fresh wounds. ${ }^{29}$ And Mattioli claimed that he had healed many cold fevers with another remedy, which he shared with Handsch "pro secreto" 30

Physicians who possessed powerful secret remedies could even hope to turn them into an important source of financial profit. Handsch wrote that Lehner was so intent on keeping secret the formula for an electuary he had developed that he had the ingredients produced by three different apothecaries. He asked a lot for the remedy, charging twelve large silver coins for an ounce of it. ${ }^{31}$ Others sold the formula for their secretum for a steep price. From a certain Hans Kochmüller - he was clearly not a physician - Handsch received the recipe for a remedy against wounds for which Kochmüller's employer, a knight, had allegedly paid eighteen

24 Cod. 11183, fol. 381v.

25 Cod. 11205, fol. 413v; on the medicinal use of hazelwort since antiquity see Marzell, Haselwurz (1958).

26 Cod. 11200, fol. 4r.

27 Ibid., fol. 25r; see also the "Experimenta et secreta Doct. Gerhardi Medici Archiducis Ferdinandi”, which include a "secretum expertum ad ischiatiken" (ibid., fol. 142v); Cod. 11006, fol. 181r: "Ad gibbum secretum doctoris Petri regii medici”. On the rich early modern semantics of the term secretum, which could refer to manifold forms of secret knowledge as well as to very concrete instructions on how to make certain medicines and other substances see Eamon, Science (1994) and Eamon, How to read (2011).

28 Cod. 11006, fol. 3 r.

29 Ibid., fol. 1v.

30 Cod. 11183, fol. 115v.

31 Cod. 11200, fol. 162r. 
gold gulden. ${ }^{32}$ Handsch also heard that a buyer paid sixty gulden for the recipe for an electuary against all kinds of poison; it was said that it had proven effective against the plague. ${ }^{33}$ And one Paduan physician purportedly even earned several thousand gulden with pills that supposedly protected against the plague for an entire month. ${ }^{34}$

Not all "secret remedies" were kept secret. On the contrary, they were often passed on to students and colleagues without remuneration. ${ }^{35}$ Speaking to his students, Willenbroch praised pills made with hound's tongue (cynoglossum) as a "secretum" that alleviated pain at night and encouraged evacuation in the morning. ${ }^{36}$ Mattioli told Handsch "pro secreto" that the seeds and leaves of stinging nettle worked like magic to stop bleeding, as he had often seen himself with head wounds. ${ }^{37}$ Numerous secreta were even published in print. Then, of course, they no longer gave their inventors and an initiated few an edge over the competition. By sharing proven secreta, however, the inventor was able to present himself as selfless, and he could also expect that his colleagues would reciprocate by passing on their own proven secret recipes. Ideally, the name of the remedy would remain tied to his own name and bolster his reputation. In the recipe books of laypeople, we find numerous formulas for remedies that were passed on under the name of the physician who (supposedly) invented them.

\section{Paracelsianism and Chymical Medicines}

Handsch's working life as a physician happened to unfold during a time when the teachings of Paracelsus (1493-1541) were finding increasing reception. ${ }^{38}$ of Paracelsus's major works, only his treatise on the French disease and his Grosse Wundartzney (Great Surgery) were in print during his lifetime, along with a series

32 Cod. 11251, fol 18r.

33 Cod. 11200, fol. 187r.

34 Cod. 11205, fol. 20v.

35 Cod. 11006, fol. 183v, on a proven secret remedy Alvise Bellicato in Padua gave away in his lecture ("in lectione pro experto secreto traditum").

36 Cod. 11183, fol. 486v.

37 Cod. 11207, fol. 146v.

38 The literature on Paracelsus and Paracelsianism is vast. The studies of Karl Sudhoff (esp. Sudhoff, Versuch (1898/99)) remain indispensable. Among the important more recent works are Pagel, Weltbild (1962), Grell, Paracelsus (1998); Williams/Gunnoe, Paracelsian moments (2002); Webster, Paracelsus (2008). 
of astrological prognostica. ${ }^{39}$ In the 1560s and 1570s, however, Alexander von Suchten, Adam von Bodenstein, Michael Toxites, Gerhard Dorn, and other proponents of a "new medicine" began to collect and publish the unpublished works, and to actively spread the word about his teachings. A notable number of medical professionals, but also princes ${ }^{40}$ and other laypeople, began to take an interest in the Paracelsian teachings and especially in Paracelsian remedies. ${ }^{41}$ As early as 1563, the physician and mathematician Georg Joachim Rheticus, who was himself very interested in alchemy, told the Nuremberg physician Joachim Camerarius from Cracow that he saw a burgeoning new school in Germany whose originator was Paracelsus. $^{42}$

The Paracelsians presented their medicine as something fundamentally new, as a radical departure from traditional medicine as taught at the universities. They accused the proponents of such medicine of slavishly adhering to the words of Hippocrates, Galen, and Avicenna. For their part, the proponents of the Galenic-Hippocratic tradition countered such accusations with fierce criticism. In the early 1570s, Thomas Erastus made a move to settle the score, publishing his extensive and widely-read Disputationes de medicina nova Philippi Paracelsi. ${ }^{43}$ Much of the scholarship and historiography of Paracelsus has foregrounded these tensions and in some cases adopted the self-presentation of the Paracelsians as the sole proponents of a new, empirically-based medicine who - finally! - were opposing the dusty book-knowledge of the Galenics, paving the way to a brighter future. ${ }^{44}$ Thus Paracelsians and anti-Paracelsians have been presented as two warring camps and the attempt has been made to classify physicians who were active at the time as belonging to one or the other. In particular, efforts have been made to identify adherents of Paracelsus in order to map out his growing influence. Often no more than a certain knowledge of Paracelsian ideas or a simple interest in alchemy and distillation has been taken as proof of Paracelsian tendencies or even discipleship.

39 Paracelsus, Von der frantzösischen Kranckheit (1530); Paracelsus, Grosse Wundartzney (1536).

40 Trevor-Roper, Court physician (1990).

41 For a very useful introduction especially into early Paracelsianism, with an extensive bibliography see the editors' introduction to Kühlmann/Telle, Frühparacelsismus (2001), pp. 1-39.

42 Letter from Rheticus, 1 February 1563, ed. in Kühlmann/Telle, Frühparacelsismus (2001), pp. 77-78: "In Germania novam sectam pullulare video, auctore Theophrasteo Paracelso." At the time, the term "sect" ("secta") which is used primarily in religious contexts today, was taken, in particular, to refer to different philosophical schools like the Stoa and the Aristotelians.

43 Erastus, De medicina nova (1572/73); Karcher, Erastus (1957); Gunnoe, Erastus (1994).

44 On the meaning of “experience” in Paracelsus" works see Bianchi, Il tema (2002). 
Looking at the writings of the self-proclaimed Paracelsians and the rebuttals of some of their opponents can indeed create the impression of two hostile and irreconcilable parties standing opposite each other across a deep divide. Taking this perspective comes with a danger of obscuring the many intermediate positions, however, especially when looking at the early days of Paracelsianism. Physicians with a Galenic orientation exhibited at times a selective openness to Paracelsian innovations, especially to the "chymical" remedies that were endorsed by the Paracelsians and which even then looked back on a centuriesold alchemical tradition. In recent times, authors such as Wilhelm Kühlmann, Joachim Telle, and Tilmann Walter have found significantly more nuance and complexity than is conveyed by the traditional dichotomous image. ${ }^{45}$

Yet, historical research continues to rely in large part on Paracelsian texts and on public polemics, and therefore on sources that tend to bring antagonisms into focus. So far, there has been a dearth of substantial studies on the reception and application of Paracelsian concepts and remedies in the practice of physicians who stood in the Galenic tradition. Handsch's notes only give insight into the world of a limited number of physicians working in the milieu of the Habsburg courts in Prague and Innsbruck. Nevertheless, they are illuminating. Even within this relatively small world, there were different positions and on the whole a remarkable openness for certain aspects of Paracelsian teaching and practice.

Georg Handsch himself has played a modest role in the historiography of Paracelsianism. Kühlmann and Telle, following Karl Sudhoff, have seen in him evidence of an "alchemo-Paracelsianism" in the court of Archduke Ferdinand. ${ }^{46}$ Their

45 Kühlmann/Telle, Frühparacelsismus (2001); Walter, New light (2012).

46 Kühlmann/Telle, Frühparacelsismus (2001), pp. 457-459; the two found further evidenc for the Archduke's alchemo-Paracelsianism in his employment as court physicians of Mattioli, who, they claim, shared the aims of an "alchemia medica" (ibid., p. 457), and of Johann Willenbroch. They also point to a request of the Tyrolean government, in 1563, that the Carinthian estates procure various Paracelsian manuscripts; it is not clear, however, whether Ferdinand himself or one of his officials was behind this request. Handsch's notebooks do offer two other remarkable pieces of evidence, which Kühlmann and Telle did not know. They mention a "senex alcumista" (Cod. 11183, fol. 354r), who was called to the bed of the dying daughter of Frau von Loxan at the court in Ambras (he only prescribed some herbal remedies against putrefaction, however), and in another entry Handsch quoted under the heading "alcumistica" a certain "old Mathias" ("senex Mathias"), possibly referring to the same man (Cod. 11205, fol. 222v). 
sources are two manuscripts by Handsch that include "Paracelsian material" in the Nationalbibliothek in Vienna, ${ }^{47}$ as well as a manuscript with Handsch's "Medicinalia" in the Wellcome Library in London. ${ }^{48}$

Upon closer inspection, the London manuscript presented by Kühlmann and Telle proves to be unsuitable as evidence. It only contains, in a foreign hand and amidst numerous other "chemical" recipes, a brief instruction for the production of medical antimony which is signed (again in a foreign hand) with "Gregorius Handschius medicus Pragensis A ${ }^{\circ} 1556$ ”. Handsch never used the first name Gregor (rather than Georg). ${ }^{49}$ It therefore appears that he was merely quoted here for a little less than two pages. ${ }^{50}$ By contrast, the Vienna manuscripts presented by Kühlmann and Telle - as well as other notebooks by Handsch - do contain several references to "chymic" medicines, indeed even lecture notes ${ }^{51}$ as well as excerpts from the writings of Paracelsus about the French disease and from his work about the miners' sickness. ${ }^{52}$ They clearly document Handsch's interest.

In printed works, taking a distinct position and setting oneself off from divergent conceptions and practices of other authors, necessarily played a salient role and was not infrequently the very reason for a publication. As opposed to this, Handsch's notes show in their openness above all, in their forgoing of a blanket devaluation or repudiation, just how blurred the boundaries were between the proponents and opponents of Paracelsian teachings. The fiery, often polemical debates found in printed works hardly find expression in Handsch's notes. In everyday medical practice, it turns out, the opposition was far less pointed than the polemical writings of Adam von Bodenstein or Thomas Erastus would have us believe, as would the historiography on Paracelsianism that followed. Clearly we must not consider physicians of the period to have been Paracelsian just on the basis of some Paracelsian or alchemical passages they penned.

47 Cod. 11200 and Cod. 11206.

48 Wellcome Library, London, Western Manuscripts 330.

49 Ibid., foll. $18 \mathrm{v}-19 \mathrm{r}$.

50 In his commentary on Dioscorides, Mattioli mentioned a recipe for antimony that he had from Handsch and reported about Handsch's positive experiences with taking antimony in times of plague (Mattioli, Commentarii (1565), p. 1348). Presumably thanks to Mattioli, Handsch was still quoted (as "Giorgio Hendschio") around 1650 in testimony of the beneficial effects of antimony against the plague (Serpetro, Mercato (1653), p. 162).

51 Cod. 11205, fol. 130r, "in Paracelso", on a solution of antimony; ibid., fol. 151v, "dicit Theophrastus", on the blood cleansing effects of antimony.

52 Cod. 11206, foll. 134r-143r, excerpts from "Von der französischen Kranckheit”, Nürnberg 1552; some further notes follow under the heading "Ex libello de ligno Guaiaco" (ibid., foll. 143r-144r). 
As can be concluded from Handsch's notes, Handsch and the physicians he worked with - they included mainly the personal physicians to the Archduke were only minimally interested in Paracelsus's new medical theories and were most certainly not interested in his theology. One would search in vain in Handsch's notes for more detailed accounts of Paracelsian concepts such as the archeus, the inner and the outer body, and the three Paracelsian principles sulfur, salt and mercury which were to take the place of the traditional four natural humors in the body. Only with reference to Johann Willenbroch (whose therapeutic approaches Handsch criticized vehemently on many occasions) do Handsch's notebooks suggest a more extensive adoption of Paracelsian concepts. Willenbroch traced diseases to "tartar", 53 and explained to Handsch that it was not always true that contrary heals contrary. ${ }^{54}$ At one point, Handsch commented that Willenbroch seemed to follow Theophrastian medicine when Willenbroch advocated for a different therapeutic approach in a patient: Willenbroch held that fluids had collected in the sick person's stomach as well as a certain spiritus that liquified the food and turned it into winds or flatulence. ${ }^{55}$

Most physicians with a Galenic training who were interested in Paracelsianism quite clearly were not attracted by the new concepts. Rather, they hoped to learn about new, improved, and more effective medicines. Handsch, Mattioli, and other physicians in their professional environment expressed openness toward "Paracelsian" medicines, and toward "chymically" produced medicines on the whole so long as they promised to cure diseases more effectively. ${ }^{56}$

The image of slavish trust purportedly invested by learned physicians in the works of Avicenna, Galen, and Hippocrates, in opposition to which Paracelsus, in his Labyrinthus of 1553, positioned the light of nature as the true source of knowledge, was, as will have become sufficiently clear, a grotesque caricature. Not only Paracelsus but also the Galenic physicians were increasingly voicing skepticism about Avicenna's Canon. ${ }^{57}$ In both their teaching and practice, they too had long come to the conclusion that personal, empirical observation of patients was to be a central methodological guidepost in diagnostics and

53 Cod. 11206, fol. 15v: "Sequitur in hoc Theoprastum de Tartaro."

54 Cod. 11183, fol. 372r; "quod contraria contrariis curentur”; Ferdinand II had burnt his finger with sealing wax and Willenbroch advised him to hold the finger close to a fire.

55 Ibid., fol. 160v, "qui videtur sectari Theophrasticam medicinam".

56 Nancy Siraisi (Siraisi, Medicine (2012), p. 499) has arrived at the same conclusion: "Many more practitioners seem to have made some use of Paracelsian remedies than espoused Paracelsus's belief system as a whole."

57 Kühlmann and Telle have rightly underlined this shared critique of Avicenna and "Arabic" medicine (Kühlmann/Telle, Frühparacelsismus (2001), pp. 470-472). 
therapeutics. And their esteem for the Hippocratic and Galenic teachings and remedies was founded not least of all on the conviction that this medicine had proven its validity empirically over the course of centuries. Given this appreciation for empiricism, even the most convinced Galenists had good reason to explore the effects and uses of chymically-produced and Paracelsian medications, whose outstanding effects had been touted in numerous reports.

This was true all the more when Paracelsians promised effective remedies against ailments for which traditional treatment was known to fail almost inevitably - diseases such as the plague, gout, epilepsy, dropsy, and leprosy. ${ }^{58}$ In this context, the physicians' interest in Paracelsian and chymic medicines was no different than their interest in old and new medicinal plants and in numerous experimenta and secreta, which were said to have a powerful effect against certain diseases, without there being any explanation for these effects. ${ }^{59}$ As we will see, this empirical outlook led some physicians even to accept that amulets and healing charms could be effective: After all, there were numerous reports by physicians and other credible witnesses attesting to their successful application. ${ }^{60}$

In a dedicatory letter to Handsch's employer Archduke Ferdinand, Adam von Bodenstein praised the refined and purified medications of the Paracelsians as more beneficial than the coarse substances of Galenic medicine, which had yet to cure any patients suffering from leprosy, gout, or the French disease, or who were crippled. ${ }^{61}$ And indeed Paracelsians were eagerly advancing the production and medical application of "quintessences" and of other "chymically" produced medicines. According to neoplatonic doctrine, the quinta essentia stood above the elements, was indeed of a "celestial nature" ${ }^{62}$ Willenbroch compared it with the human soul. ${ }^{63}$ In practice, however, the term "quintessence" referred to medicines whose faculties or essence - which transcended the four elementary primary qualities and remained concealed - one could attempt to distill and thus concentrate and free of admixtures.

58 In his dedicatory epistle to Paracelsus, Bergsucht (1567), the editor declared the successful cure of podagra, epilepsy, leprosy and dropsy - diseases that were widely deemed incurable the touchstone for the efficacy of Paracelsian medicines; Handsch excerpted the passage (Cod. 11206, fol. 161v).

59 Kühlmann and Telle have found a similar approach, for example, in the case of Rheticus and reject the claims of some scholars that he was an enthusiastic follower of Paracelsus (Kühlmann/Telle, Frühparacelsismus (2001), pp. 102f.).

$60 \mathrm{Cf}$. the chapter on witchcraft and magic below.

61 Dedicatory epistle, 24 December 1571, in Bodenstein, Metamorphosis (1572).

62 Cod. 11207, fol. 89v.

63 Cod. 11205, fol. 2v. 


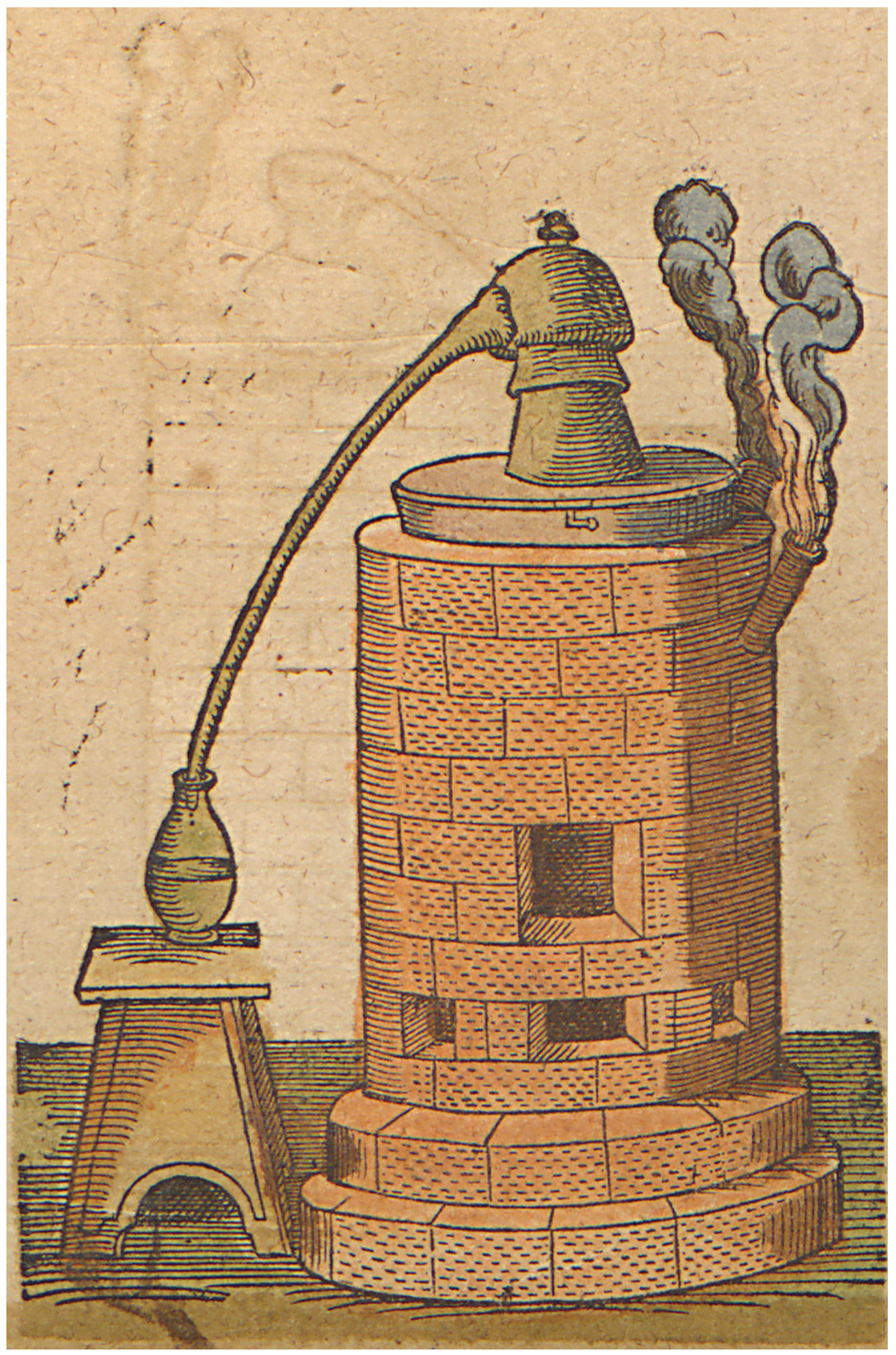

Fig. 10: Distilling oven (balneum Mariae) in: Pietro Andrea Mattioli, Kreutterbuch, 1611, Universitätsbibliothek Erfurt, Sign. 13 - MA $2^{\circ} 23$ t.

The production of such quintessences was not a unique feature of Paracelsian medicine. The processes and apparatuses involved had been known for a long time, not least of all from the art of distilling spirits. At the theoretical level, Jean Fernel in his influential works had increasingly drawn attention to 
"occult" qualities and powers and to the ancient Galenic concept of diseases and medications whose effects could only be explained with respect to the "total substance", the tota substantia. ${ }^{64}$ Diseases of the total substance could not be attributed to humors or to elementary qualities. They were specific, had their own essence. When Handsch, having read Paracelsus's work about the French disease, uncharacteristically wrote about Paracelsian theory, his comment very much followed in this vein: "He attributes the causes of the diseases to the specific substantial qualities." 65 Medicines and poisons that took effect through their total substance similarly had at their command specific - and ideally particularly powerful - faculties which could not be attributed to the primary, elementary qualities and which could only be identified and verified empirically. ${ }^{66}$

The physicians in Handsch's professional environment made widespread use of quintessences, which they understood as remedies whose specific effects were simply concentrated through distillation. Gallo's rhubarb quintessence, for example, was by no means an ethereal substance, but rather was quite pungent, sweet, brownish, and of medium consistency. As Gallo explained, he only called it "quinta essentia" because others did the same. ${ }^{67}$ Mattioli very often used his personal quintessence with patients, even with an abbot suffering from the hiccups, which then immediately stopped. ${ }^{68}$ When Ferdinand II was suffering from stones, his physicians gave him scorpion oil with a few drops of quintessence. ${ }^{69}$ From the "chymist" Jacobus Gallus, Handsch learned how to make a whole array of essential oils "per alcumisticam [sic] artem". They each had their own indications for different diseases, and Gallus discussed with him such things as using oil of vitriol to treat hot fevers. ${ }^{70}$ Philippine Welser, too, had her own quintessence. ${ }^{71}$

It is telling that Handsch called Mattioli's "quintessence" simply "aqua vitae", which was the contemporary term for brandy. ${ }^{72}$ Michael Schrick's treatise Von den

64 Bianchi, Occulto (1982), pp. 188-212; Richardson, Generation (1985).

65 Cod. 11206, fol. $134 \mathrm{r}$.

66 Cf. Argenterio, De morbis (1556), p. 217, on the humores: "Sunt qui in occultis, malignisque qualitatibus naturam obtinent, vitiataque sunt forma, quales sunt, qui in aere pestilenti gignuntur, aut a venenis tota substantia laedentibus inficiuntur."

67 Cod. 11207, fol. 89v.

68 Cod. 11207, fol. 27r and fol. 85a v.

69 Cod. 11204, fol. 54r.

70 Cod. 11205, foll. 128v-134v, cit. fol. 128v: "Quae a Iacobo Gallo chymista habuerim et didicerim". It is unclear whether the man's name was "Gallus" or whether "Gallus" has to be translated as "Frenchman", as the first name "Jacques" and the fact that Handsch mentioned previous activities in France suggest.

71 Cod. 11183, fol. 481v.

72 Ibid., fol. $135 \mathrm{v}$. 
ausgebrannten Wassern (On Distilled Waters), written in the fifteenth century, was reprinted many times in the sixteenth century and reached a wide audience. In it, Schrick presented distilled (and for the most part non-alcoholic) waters from dozens of different plants and described their applications. ${ }^{73}$ The appendix to Handsch's German translation of Mattioli's commentary on Dioscorides showed the reader various types of distillation ovens and described the method by which the "subtlest and best part of the herbs [was] separated from the coarsest". 74 Made of tin or glazed clay, the "Rosenhütte", for example, allowed the distiller to place vessels with fresh, minced herbs in water or wine on hat- or bell-shaped structures that were arranged in several levels in a circle. If a fire was kindled in the oven, the heat would cause steam to rise into the little hats. It would then become liquid in the cooler parts of the hat and the distillate would run off into the vessel via an outlet or spout and could be collected. ${ }^{75}$ Distilling with less intense heat was possible using a balneum Mariae, or bain-marie, whereby the contents of the distillation flask were heated from below in a copper bowl filled with water, which was heated with fire (cf. Fig. 10). ${ }^{76}$

The central innovation advanced by the Paracelsians was the widespread use of mineral and metallic preparations. With Paracelsianism, they attained a standing in medical treatment that was unprecedented. But even the most avid advocates of Paracelsian medicine ${ }^{77}$ conceded that these substances already had held a place in older medicine. Handsch wrote that even Galen had used arsenic or similar substances to treat disease in individual cases. ${ }^{78}$ In Padua, Falloppia strongly recommended oleum vitrioli to his students as a remedy for worms, ${ }^{79}$ and this substance was also prescribed in Handsch's environment in Prague for a number of different diseases. ${ }^{80}$ According to Sigismund Melanchthon, learned physicians were generally aware of

73 Schrick, Von den ausgebrannten Wassern (1481); Brunschwig, Destillierbuch (1512); Brunschwig, Buch (1519).

74 "Ein kurtzer leichter Begriff und Unterricht, künstliche Destillier oder Brennöfen mit zugehörender Bereythschafft zu machen”, in: Mattioli, Kreutterbuch (1563), foll. 570v-574r.

75 Ibid., foll. 570v-571r.

76 Ibid., fol. 572r.

77 Dedicatory epistle of the architect Samuel in Paracelsus, Bergsucht (1567).

78 Cod. 11238, fol. 141r, on Galen's recommendation of clysters with arsenic against intestinal ulcers; according to Handsch's Padua notebooks, a certain Ludovicus - perhaps Tremenus prescribed such a clyster but with limited success.

79 Cod. 11251, fol. 40v.

80 According to a letter from Conrad Gessner to Johannes Muralt, Muralt used oil of vitriol against diseases of the uterus; Gessner was critical, however, because of the corrosive effects (www.aerztebriefe.de/id/00000251, S. Weidmann). 
its use around $1570 .{ }^{81}$ In one place, Handsch even expressed skepticism about Falloppia's use of a herbal remedy, writing that mineral remedies would have been a better choice. $^{82}$

When physicians with a Galenic background voiced their criticism of the metallic or mineral medications used by Paracelsians, they were not attacking the metallic, mineral or otherwise chemically-prepared substances as such, but were speaking up about the dangers associated with them and the hyperbole concerning their effectiveness. Caspar Hofmann, for example, stated in 1575 that while some liked to sing the praises of oil of vitriol, the ingestion of such a caustic, acrid substance came with great dangers. He had seen patients die in agony from it. ${ }^{83}$ Even the aged imperial court physician Johannes Crato explained that although he certainly used chymic remedies with success, he opposed the claim that they worked miraculously, and he would not be moved to assent to the doctrine as a whole. ${ }^{84}$

The fiercest disputes revolved around extremely toxic antimony, known in German as "Spießglanz". Particularly in France, it was a major point of contention between the Paracelsians and the proponents of orthodox medicine. ${ }^{85}$ In Prague and many other cities, on the other hand, physicians were significantly more at ease when dealing with the new substances, including even antimony. While antimony was controversial, it was by no means only accepted by the self-proclaimed followers of Paracelsus. Mattioli, for example, used antimony to treat patients and discussed its production with Handsch. ${ }^{86}$ Handsch himself gave some patients in Leipa antimony, especially women with disordered menstruation. With some, he found, it produced good effects. ${ }^{87}$ He wrote that if someone expressed misgivings about antimony, one could reply that science ("scientia") knows no enemy except the ignorant. ${ }^{88} \mathrm{~A}$ "chymicus" showed him

81 Letter from Sigismund Melanchthon to Joachim Camerarius, Nürnberg, 13 January 1570, (www.aerztebriefe.de/id/00000054, S. Wenning).

82 Cod. 11251, fol. 67v.

83 Letter from Caspar Hofmann to Johannes Hermann, Frankfurt [an der Oder], 1 June 1575, published in Scholz, Consiliorum (1594), pp. 380-82.

84 Copy of a letter from Johannes Crato von Krafftheim to Joachim Camerarius, Breslau, 28 January 1585 (www.aerztebriefe.de/id/00008399, S. Wenning).

85 Debus, French Paracelsians (1991), pp. 21-30, and on the ongoing conflicts in the seventeenth century, ibid., pp. 95-99; Nance, Turquet de Mayerne (2001), pp. 25-30.

86 Cod. 11205, foll. 131v-132r.

87 Ibid., fol. 122v.

88 Ibid., fol. $132 \mathrm{v}$ 
how it was produced. It was not a simple process. The raw antimony had to be heated on a hot coal fire for several hours to separate the arsenic and sulfuric parts. ${ }^{89}$ The work was also dangerous, as the apothecary Jeremias impressed upon Handsch and Mattioli when he showed them the production process ("calcinatio"). ${ }^{90}$ To protect oneself from the rising vapors, it was necessary to plug one's nose. He told them about a physician who had a special hood made that exposed only the eyes. The toxic vapors were likely also the reason why the apothecary availed himself of a portable stove that could be used outdoors. ${ }^{91}$

Handsch tried, by himself and with Mattioli, to produce medicinal antimony, but he failed various times. ${ }^{92}$ Conrad Gessner, too, attempted to produce it during these years but ultimately had to ask for help from the Nuremberg physician Dr. Herold. ${ }^{93}$ Joachim Camerarius, the founder of the Nuremberg Collegium medicum, requested detailed instructions for the production of antimony, ${ }^{94}$ and even the well-known astronomer Tycho Brahe wanted to learn about the process. ${ }^{95}$

In one entry, Handsch even wrote down verses from the Carmen elegiacum by Michael Toxites, a well-known advocate of Paracelsianism. The work was a poetic riposte to the criticism of the Augsburg physician Lucas Stenglin about the use of antimony. ${ }^{96}$ Here Handsch learned that when the antimony was "purged" in the fire, it was no longer toxic. The fire rendered it innocuous. At the same time, Toxites held that the illnesses physicians were dealing with were more severe than in earlier times due to widespread gluttony - the excessive enjoyment of meat, fish, and the like. Moreover, there were new "contagia" which were not mentioned in the old books. For these reasons, metallic medicines such as antimony were necessary as they were equipped with more powers than herbal remedies. And some traditional medicinal plants such as hellebore were incidentally

89 Cod. 11183, foll. 147r-152v.

90 Ibid.

91 Cod. 11205, fol. 132v.

92 Ibid., fol. 131v and fol. 132a v; in a marginal note, Handsch mentioned his failed attempt at making medicinal antimony "apud comitem", possibly referring to his time as a student in Padua with Comes de Monte.

93 Letter from Conrad Gessner to Hieronymus Herold, 27 January 1565 (www.aerztebriefe.de/ id/00000249, S. Weidmann).

94 Letter from Gabriele Beati to Joachim Camerarius (1580) (www.aerztebriefe.de/id/ 00000385, U. Schlegelmilch).

95 At any rate, Heinrich Wolff promised Brahe that he would do everything so that Brahe could learn how to make antimony (copy of a letter, 11 November 1571, www.aerztebriefe.de/ id/00004487, U. Schlegelmilch).

96 Cod. 11183, foll. 291r-293r; cf. Toxites, Spongia (1567); on the frontispiece, Toxites called himself explicitly a "Paracelsi discipulus". 
also poisonous and potentially harmful. To complement the verses, Handsch also excerpted relevant passages from a letter Michael Toxites had written to Mattioli. ${ }^{97}$ Here too, Toxites praised the effects of antimony, which could help heal almost any disease. Caution was only advised with patients whose brains were weak and with those for whom the vomiting caused by antimony was dangerous due to a tightness in the chest and veins. What was important, of course, was correctly preparing it. Paracelsus himself had described different antimony preparations, of which the white and red antimony flowers ("flores antimonii albi et rubentes") were the most excellent. A tincture made from the reddish antimony flowers cleansed the blood in such a way that an illness could not easily occur. This was the antimony liquid ("liquor stibii") that some earlier philosophers had mentioned but about which they had not gained complete knowledge.

In Handsch's notebooks, antimony figures simply as a promising medicinal product to be used with caution, which - like many other "tried and tested" remedies - produced good effects when used with certain diseases. ${ }^{98}$ Handsch's own brother was first purged with antimony before he received external treatment for his scabies. ${ }^{99}$ Handsch himself took antimony during a plague epidemic and experienced a laxative effect. ${ }^{100}$ He observed the same effect in a patient to whom he administered antimony when the man was experiencing signs of paralysis in his leg. He had learned about the beneficial effects of antimony in another case with a patient who was experiencing similar symptoms. ${ }^{101}$

The opposition, at least in these early times, between traditional Galenic medicine and the "new" Paracelsian medicine also proves to be less pronounced than is suggested by the polemical disputes if we look at the evidence documenting the actual practice of physicians who explicitly espoused Paracelsian doctrine. In one of his notebooks, Handsch gave a detailed description of a consilium by Paracelsus for Bernhard Reichlinger in Augsburg. ${ }^{102}$ Reichlinger was suffering from intense pain during urination and was only able to empty his bladder - if at all - with the help of a catheter. Paracelsus explained to the patient that the cause of his complaints was yellow bile. As treatment he recommended trochisci

97 Cod. 11183, foll. 293r-294r: "In literis ad Matthiolum”. Toxites is not explicitly named as the author but the entry follows immediately after an entry on Toxites' Carmen and seems to have been written with the same ink and quill.

98 Ibid., fol. 292r; Cod. 11204, fol. 46r, on the successful use on a dropsical patient.

99 Cod. 11207, fol. 64r; the entry carries no date but goes back to Handsch's time with Gallo, around 1555 .

100 Cod. 11183, fol. $124 \mathrm{v}$.

101 Ibid.

102 Cod. 11200, foll. 240v-241v, “Consilium D. Theophrasti Paracelsi”, with additional notes by Handsch. 
(large cookie-like pills) made from physalis alkekengi (bladder cherry) and olibanum (frankincense). To improve urination, Reichlinger was also to use a secret remedy for fourteen days, a "heimlich Stück" or "secret piece" as Paracelsus called it: this was finely crushed pure crystal, to be mixed into white wine and drunk. This would drive all the yellow bile that was making him sick out of his body. His stones would be gone. If, against all expectations, he still had trouble urinating in spite of the remedies, he could tie a small satchel of saffron on his "pipe" (penis) and then the urine would flow. ${ }^{103}$ It seems the yellow saffron was to pull the yellow urine out of the body. Paracelsus's explanation of the medical condition might just as well have been the explanation of an "archconservative" Galenist, just as his treatment with plant-derived substances could have come from one. The only procedure that was somewhat special was the use of crystal as a secretum and the external application of saffron with the help of a little satchel, which, as we will see, was documented for other physicians of the time as well.

To give another example, the way in which, according to Handsch's notes, an unnamed "physician of the Theophrastian discipline" explained the intense abdominal pain of a member of the Tucher family to him could have easily come from an opponent of Paracelsus. Having performed a thorough examination of the urine, the man explained that the patient's bile was corrupted in such a way that it was no longer of service to the liver, and that it was spoiling both liver and blood. ${ }^{104}$

Even someone like Bartholomäus Carrichter, who made explicit use of Paracelsian concepts like the three principles of mercury, salt, and sulfur ${ }^{105}$ and the "tartaric fluids", ${ }^{106}$ does not seem immediately subsumable as Paracelsian when we look at the way he treated his patients. In historical research, Carrichter is widely considered a Paracelsian and was coopted as such by Michael Toxites. ${ }^{107}$

103 Alternatively, Paracelsus recommended using the blood of a hare and a fox, in equal quantities, which had been dried in a baking oven.

104 Cod. 11183, fol. 158r; almost identical: Cod. 11206, fol. 15v.

105 E.g. Biblioteka Uniwersytecka Wrocław, Collection of the church library of Maria Magdalena, M 1024, fol. 1v, on an Augsburg citizen with an obstruction of the nerrus opticus "ex resolutione crassi mercurii a resplendenti sulphure terrestri”, and ibid., fol. 6r, on various symptoms of an "exustio mercurii et sulphuris".

106 Biblioteka Uniwersytecka Wrocław, Collection of the church library of Maria Magdalena, M 1024 , fol. $4 \mathrm{~V}$

107 On Carrichter and his (alleged) Paracelsianism see Telle, Carrichter (1997). 
Yet, his extensive practice journal from around $1560^{108}$ contains countless diagnoses and explanations that could have easily come from the case histories of orthodox Galenic physicians. Sometimes Carrichter made direct reference to the four natural humors. He identified a quartan fever caused by an obstruction of the spleen in a patient with a sanguine temperament, ${ }^{109}$ an excess of mucus in the body ${ }^{110}$ or black bile, ${ }^{111}$ cases of melancholy ${ }^{112}$ and of melancholic hypochondria, itching caused by burnt black bile, ${ }^{113}$ headaches or joint pain caused by black bile ${ }^{114}$ and so forth. In addition came other classical humoral-pathological diagnoses such as "dripping catarrh" (catarrhus destillans), ${ }^{115}$ a putrefaction of the lungs, ${ }^{116}$ and an obstruction of the mesenteric veins. In the vast majority of cases, therapy involved plant-derived remedies rather than chemical medicines. Carrichter was known to have a profound knowledge of plants and was said to have shown Mattioli more than a hundred plants, which Mattioli then published in his commentary on Dioscorides. ${ }^{117}$ Carrichter himself became well-known for his own herbal book, in which he made a point of specifically considering the astral influences during the collection of herbs. ${ }^{118}$

As the extensive consilia of Leonhard Thurneisser, court physician to Elector Johann Georg of Brandenburg, show, this self-professed proponent of Paracelsianism also relied on Galenic concepts to a great extent when interpreting and explaining illness. Thurneisser traced his patients' illnesses to "böse Flüsse" ("bad fluxes"), vicious mucus, rising vapors, obstructed veins and organs, and so forth. Like that of his Galenic colleagues, his treatment aimed primarily at "cleansing" the body, the blood, or individual organs such as the uterus, at "opening" the body with purgatives and at "strengthening" certain organs. The most important difference vis-à-vis orthodox Galenic practice was the additional use of valuable

108 National Library of Medicine, Bethesda, Ms. E63; Biblioteka Uniwersytecka Wrocław, Collection of the church library of Maria Magdalena, M 1024 (the two manuscripts are in large parts but not entirely identical).

109 Biblioteka Uniwersytecka Wrocław, Collection of the church library of Maria Magdalena, M 1024, fol. 3v.

110 Ibid., fol. 17v and fol. 20r.

111 Ibid., fol. 5r, fol. $14 \mathrm{r}$ and fol. $17 \mathrm{r}$.

112 Ibid., fol. 16r.

113 Ibid., fol. 19v and fol. 22v.

114 Ibid., fol. 19r and fol. 21r.

115 Ibid., fol. 23v.

116 Ibid., fol. 21v.

117 Letter from Conrad Gessner to Johannes Crato, 1 August 1563, according to Helmich, Briefe (1938), pp. 34-35.

118 Carrichter, Kräutterbuch (1609). 
and expensive medicines such as corals and gems, to which Thurneisser ascribed special healing powers. ${ }^{119}$

Since they needed to accommodate the medical notions and the expectations of their patients, it is not surprising that Paracelsian physicians were ready to avail themselves of Galenic explanatory models and purgative remedies, when dealing with patients and their relatives. For laypeople, the hope that the new or rare substances advanced by the Paracelsians, such as "chemical" medicines, would have miraculous effects certainly had its place. But complex new theories of disease, such as the doctrine of the three Paracelsian elements were much more difficult to communicate.

To summarize, a certain openness among learned physicians toward Paracelsian medicines must by no means be taken to prove that they were followers of Paracelsianism. The notion of a radical alterity of Paracelsian medicine - its irreconcilable opposition to the medicine of "Galenic" physicians - is untenable, certainly with respect to the 1560 s and 1570 s when Paracelsian literature and ideas were increasingly finding an audience. Those primarily responsible for drawing the distinction were the self-proclaimed proponents of Paracelsianism. Like Handsch and his colleagues, the Paracelsian proponents hoped for a new and more effective art of medicine. But they also wanted to position themselves in the health market as the advocates of a new medicine that was especially promising because it relied on new concepts and remedies. They wanted to secure for themselves the support of princes and other wealthy patrons, and some Paracelsians were very successful in their efforts.

\section{Experimental Drug Trials}

In their search for new and improved medicines, physicians were very aware of the great methodological difficulties involved in truly establishing efficacy. They agreed with Galen that when a disease took a favorable course after a certain medication had been administered, this could only serve as proof of its efficacy to a very limited extent. It was necessary to repeat the trial and to observe the patient, and even then, there was no guarantee of certainty. Reading Galen's commentary on the Hippocratic aphorisms, Handsch wrote, "Even testing a medicine six or seven times does not permit a general conclusion". ${ }^{120}$ Much like the

119 Staatsbibliothek Berlin, Ms. germ. fol. 99, 420a, 420b, 421a, 422b, 423a, 423b, 424, 425 and 426.

120 Cod. 11200, fol. 126r: "Medicina etiam sexies vel septies probata non facit universalem propositionem." 
way that the emergence of homeopathy in the early nineteenth century gave rise to the first known double-blind trial in medical history, ${ }^{121}$ the spread of Paracelsianism and the reports of the miraculous - and for many physicians suspect curative powers of Paracelsian remedies, such as theriac and various "secret remedies", ${ }^{122}$ sharpened the focus on the issue of reliable drug testing in medicine.

Handsch made note of several reasons why one had to take care not to make hasty generalizations and draw conclusions prematurely:

1) It was common knowledge in medicine that the efficacy of a remedy was always dependent of the specific circumstances of the case - the patient's physical constitution, his or her living conditions, way of life and diet, the time of year, the point of time within the course of the disease, and other external factors.

2) The trust the patient had in the medication and/or the physician could have a great influence on the healing process. Today we would speak of the placebo effect. "It is the firm belief which sometimes heals", Handsch wrote. ${ }^{123}$

3) As a rule, most remedies at the time were composed of a mixture of medicinal plants or other substances. This made it difficult if not impossible to arrive at irrefutable conclusions about the efficacy of particular ingredients. Back in his university days, Handsch when discussing with his fellow students referred to a methodological principle of drug testing, which was later underscored by Samuel Hahnemann, the founder of homeopathy, and which has essentially retained its validity today: "When we want to gain experience about the faculties of a particular plant, we have to use it on its own". ${ }^{124}$

4) The observed favorable effect of a medicine could be merely an indirect "accidental" consequence. For example, Handsch wrote, if many stools were passed after a medicine was administered, this did not necessarily mean that the medicine had a laxative effect and could be used with future patients with this indication. A medicine that was known to strengthen the stomach could ultimately produce the same visible outcome. In itself, it did not have a laxative effect, but the stomach now had a greater expulsive power thanks to the medicine. ${ }^{125}$

121 Stolberg, Homöopathie (1996). The randomized, controlled double-blind clinical trial (in which neither the physician nor the patient knows whether the drug in question is a placebo or the active substance) is widely considered the gold standard for assessing the efficacy of a remedy today.

122 Bayle, Thériaque (2011).

123 Cod. 9671, foll. 122v -123r, "fixa fides est quae sanat interdum"; see also Cod. 11207, fol. $154 \mathrm{v}$, on the efficacy of amulets, in particular.

124 Cod. 11240, fol. 99r.

125 Ibid. 
In other words, only studies with specific medicinal substances that involved patients with similar complaints and, better yet, studies that made comparisons with patients who were receiving no treatment, promised a degree of certainty. In particular, they could control for the influence of the natural favorable course of a disease, the most important reason for an error of judgment by far.

The idea of testing for efficacy, especially that of poisons and antidotes in comparative trials on humans and animals, goes back to antiquity. ${ }^{126}$ In sixteenthcentury medicine, the value of comparative trials was common knowledge. For example, Lehner told Handsch that he had tested a poison on two pigeons giving the poison to both but the antidote only to one of them - which survived. ${ }^{127}$ And a man named Bräutigam told Handsch how one could tell the difference between expensive, real powdered unicorn horn, which was considered to be a powerful antidote, from the imitation powder made from dried horse bones: One had to give two pigeons mercury sublimate and then one of them the powdered unicorn horn as an antidote. It could be expected that only the latter would survive. ${ }^{128}$

Records of comparative trials on people are extant from as early as the fifteenth century. The Portuguese king João II was severely ill and his physicians diagnosed dropsy in 1494. They considered a treatment at a healing spring to be advisable, but found themselves in a fierce dispute about whether the healing spring in Óbidos was more appropriate than the one in Monchique. To settle the question, the story goes, "many" dropsical patients, each accompanied by a physician, were sent to the two natural springs to test and compare their efficacy against dropsy. When one of these patients quickly improved in Monchique, however, the king did not wait for the results of the trial. ${ }^{129}$ In 1485, a similar trial had been done already under Queen Leonor to determine which of the three healing springs near Óbidos should serve as a location for a thermal hospital. Three patients suffering from the same disease were each sent to one of the three springs. ${ }^{130}$

By and large, the conditions for systematic comparative studies on humans remained unfavorable until well into the eighteenth and early nineteenth century. Before that time, there were hardly any hospitals with a larger number of victims of the same disease on whom the physicians could have performed comparative

126 Touwaide, Galien (1994); a very useful introduction into the historical development of clinical trials from antiquity until today, with numerous sources, is offered by the James Lind Library (https://www.jameslindlibrary.org/).

127 Cod. 11207, fol. 3v.

128 Cod. 11183, fol. 243v; today the horn of the "unicorn" is commonly believed to have been the tusk of a narwhal.

129 Resende, Crónica (1798), p. 272; cf. Mauser, Geschichte (2013), pp. 88f.

130 Mauser, Geschichte (2013), p. 41. 
trials, withholding established medicines or therapies in order to exclude the influence of the natural course of the disease on the outcome. Moreover, early modern physicians prided themselves of basing their treatment not only on the diagnosis and the presumed pathological processes within the body, but of taking also into account the patient's individual constitution, temperament, way of life, and so forth, and modify the therapy accordingly.

Within a limited scope, however, comparative drug trials on humans were carried out systematically as early as the sixteenth century as part of the search for effective antidotes. The aim here was not only to have effective medication to treat the accidental consumption of toxic plants or mushrooms, or the bite of a poisonous animal. The deadly effects of devastating epidemics - the plague above all - were also often traced to a more or less specific morbid poison that entered the body. And for rulers, moreover, there was always the looming threat of being poisoned.

Physicians knew from experience that poisons, be they of plant, animal, or mineral origin, often could not be successfully combatted with the traditional evacuative remedies. Strong poisons, they concluded, had specific powers that transcended the elements and issued from their "total substance". 131 They could thus only be overcome, in turn, with a remedy whose powers were stronger than those of primary and secondary qualities. Such "occult", supraelementary powers could only be established or refuted by empirical observation.

In the case of poisonous plants and fungi that might be used for poison attacks, testing for the efficacy of antidotes proved to be particularly difficult. Poisonings from accidental ingestion of poisonous substances were rare, and it was even rarer that an antidote was on hand. A different way was found to conduct the research, however: giving first the poison and then an antidote to criminals who had been sentenced to death. ${ }^{132}$

Gabrielle Falloppia witnessed such a test in the 1540s in Ferrara. A cardinal from Ravenna had obtained the recipe for the celebrated oleum Clementis, an oil which Pope Clement VII was said to have composed in 1527 and which was praised for its miraculous effects against an epidemic pestilence that ravaged Rome at the time. The cardinal asked the Duke - presumably Ercole d'Este - for his permission that the oil be tried on a man who had been condemned to death. Antonio Musa Brasavola, who himself did not believe that the antidote would work, gave the prisoner a strong poison which contained sublimate of mercury. The man complained

131 Cf. Bianchi, Occulto (1982).

132 On the following see Stolberg, Tödliche Menschenversuche (2014); Rankin, On anecdote (2017). Rankin recently published a monograph on the topic (Rankin, Poison trials (2021). Unfortunately, it came out when this English edition of my book was already being preparted for print; not surprisingly, we have dealt with some of the same trials. 
that it felt as if a fire were burning inside him and after several hours he collapsed and seemed half-dead. At this point, the oil was applied, and within half an hour he recovered. He lived for another five days, plagued by constant hiccoughs. According to Falloppia, even Brasavola was now almost ready to admit that the man would have survived for good if he had, in addition, been given an emetic and something to soften the caustic effects of the poison. ${ }^{133}$

Georg Handsch was personally involved in one the most widely publicized trials of this kind. In the winter of 1561-62, Pietro Andrea Mattioli tested the effectiveness of a powder in the possession of Archduke Ferdinand II. This archducal powder had allegedly been effective on many people. It had been tested, for example, on a man who was sentenced to death, and was believed to have proven successful. The man was first given arsenic and then, as he began to shake and his face began to swell and he seemed close to having a seizure, he was given the antidote. He vomited, survived, and was pardoned. In 1561, when Emperor Ferdinand I was spending time in Prague, it was decided that the efficacy of the archducal powder would be tested against aconite or monkshood, the most powerful plant poison at the time. In his notes, Handsch gave a detailed eye-witness account of the procedure and the results, and he described this first trial in his German translation of Mattioli's commentary on Dioscorides. ${ }^{134}$

The subject of the trial was a young man who had "forfeited his life with theft", as Handsch put in his published account, and who was to die the next day at the gallows. According to Handsch the man participated in the trial "very willingly indeed [. . . ] because he preferred to die (since it was going to come to this) in a quiet place with few and honest people around rather than being hanged for all the world to see". He was promised that if he survived, he would not be executed. ${ }^{135}$ In the presence of the imperial and archducal physicians, the man ingested a powder made from the root of the monkshood plant, which grew in the Bohemian mountains. When the man did not feel any effects from the poison, the physicians concluded that Bohemian monkshood was not as powerful as monkshood from faraway places, and that the poison in the roots had moved into the blossoms, leaves, and seeds. He was taken back to the dungeon. Several hours later, Mattioli gave him aconite blossoms and leaves in addition, and now the man began to experience serious symptoms. He felt pressure near his heart, and he fell to the ground like an epileptic and soiled himself. When he came to and

133 Falloppia, De tumoribus (1606), fol. 68v.

134 Mattioli, New Kreutterbuch (1563), foll. 472v-473r.

135 Ibid., fol. 473r, "dann er wolte lieber sterben (so es ja dahin gerhaten würde) an einem stillen Ort, unter ehrlichen und wenig Leuten, dann das er solt offentlich vor allem Volck erhenckt werden". 
stood up, he had no memory of the fall. At this point, Mattioli gave him the antidote in wine, the "archducal powder" - a mixture of different plants ${ }^{136}$ - and called on Handsch. Neither of them could feel the man's pulse. His face was running with cold sweat and he complained of cold. The physicians left him behind on a bed of straw, intending to return in an hour and a half. But just half an hour later, they were given the message that he had vomited and died. ${ }^{137}$

As we learn from Handsch's notebooks, another, slightly older young man had better luck, a few weeks later. He was given aconite root and, when the first signs of poisoning appeared, some bezoar. Bezoars, solidified clumps of hair and other substances that form in the stomachs of animals (and humans), were widely considered to have special powers to counteract poison. The man developed severe symptoms. His pulse raced and was weak and irregular. He vomited six or seven times. He complained of visual impairment and a coldness in his head, showed temporary signs of paralysis in his arms, but could speak the entire time. In the evening his complaints were gone. The following day, the Emperor sent him six talers and, it seems, pardoned him. ${ }^{138}$

Handsch was also present in 1564 when physicians gave monkshood and (arsenic-containing) nux-vomica to another young man who was sentenced to death. "My head feels strange, as if I were drunk" the man complained. His pulse became irregular. Then he too was given the "archducal powder". He vomited violently after sticking his finger in his throat, and had a bitter taste in his mouth. He threw his head back and his eyes bulged dramatically. He vomited again and again and was weak and fatigued. He had the feeling that his arm was liquifying. After five hours, Handsch left him. When he visited him the next day, the man was sitting at the table reading the Gospel. He was a free man. ${ }^{139}$

We also have records of a similar trial which was carried out in Florence in 1567. On the orders of Cosimo de' Medici, two men who had been sentenced to death for murder were used as subjects to test an antidote which several physicians had recommended to the prince. The two men received poison - the sap of monkshood, it was presumed - and then an antidote. They developed severe symptoms of poisoning, but survived. They were spared execution, but were sentenced to a lifetime of work on a galley. ${ }^{140}$

136 In Cod. 11183, fol. 190r, Handsch listed the ingredients.

137 Ibid., fol. 126r-v.

138 Ibid., foll. $127 \mathrm{v}-128 \mathrm{v}$.

139 Ibid., fol. $128^{\star} r-v$, inserted slip of paper.

140 Andreozzi, Leggi penali (1878), pp. 49f.; Andreozzi based his conclusion on the documents of the Compagnia del Tempio; in the Archivio criminale he found the names of the murderers and evidence for their having been pardoned. 
In Paris too, a poison trial of this kind was carried out during these years, with explicit reference to Mattioli's trials in Prague. According to the account by the famous surgeon Ambroise Paré, the French king had been shown a bezoar from Spain that allegedly counteracted poisons of all kinds. Paré was incredulous. Poisons acted in different ways, he held, and therefore required different antidotes. At his behest, a cook who had been found guilty of stealing two silver bowls from his employer and sentenced to death would be used to test the effect of the bezoar. Having been promised that he would be pardoned if he survived the trial, the cook consented to taking first the poison and then some of the bezoar to test its efficacy. An apothecary administered the poison and the antidote. The poison - according to Paré it was likely mercury sublimate - produced immediate effects. The cook vomited and his condition worsened dramatically. His bowels were burning like fire, he wailed. In the end, as Paré wrote, the man broke out in a cold sweat and crawled on the floor on all fours with his tongue hanging out. Paré then gave him oil to drink to weaken the effects of the poison, but it was too late. After seven hours of torturous pain and screaming, he died. ${ }^{141}$

Alongside these non-comparative trials, records of comparative studies have survived from as early as the beginning of the sixteenth century. They followed the model of the above-mentioned trials with pigeons. In his commentary on Dioscorides, Mattioli recounted how he, as a young physician in 1524, was present in Rome when none other than Pope Clement VII had a topical oil tested which was said to act as an excellent antidote to poisons quite possibly the same oil Brasavola tested in Ferrara. Two men condemned to death were given aconite, but only one was rubbed with the oil in the days that followed; he survived. The other man, however, who was not treated with the oil so as to "test the power of the aconite poison", died in agony. ${ }^{142}$ During his time in Padua, Handsch mentioned a similar story without naming the source or the people involved. Two men who had been sentenced to death served as subjects. One received a higher dose of aconite along with an antidote and survived, while the other received only a lower dose of the poison, without an antidote, and died. ${ }^{143}$

Further records have survived of a particularly sophisticated study that was carried out in the late 1570s in Germany. ${ }^{144}$ Here, the human trials were preceded by a comparative trial on animals. A certain Andreas Berthold, probably a mine owner, had a large-scale operation selling terra sigillata from Silesia.

141 Paré, Euvres (1575), p. 939.

142 Mattioli, Commentarii (1565), pp. $1095 f$.

143 Cod. 11240, fol. 142r, "Hystoria de duo damnatis"; perhaps this was the abovementioned trial under Pope Clement but the two accounts differ considerably.

144 Stolberg, Tödliche Menschenversuche (2014); Rankin, On anecdote (2017). 
Also known as bolus armenus, terra sigillata had been considered an effective remedy for poison and the plague since antiquity. Gallo praised its effects "against putrefaction" ("contra putredinem"). ${ }^{145}$ But it was expensive because it came from distant Armenia. In petitions and advertisements, Berthold explained that his native terra sigillata was even more effective than the imported product. It was a true arcanum against many poisons and diseases - and he wanted to prove it. He first suggested to the Basel Collegium medicum that they test the efficacy in an animal trial, but it appears his application was unsuccessful. ${ }^{146} \mathrm{He}$ fared better in northern Germany. In Jülich and at the Kassel palace, he was able to initiate trials with five pairs of dogs who would serve as trial subjects. One dog in each of the pairs was given only poison, while the other was also administered Berthold's Silesian terra sigillata. The results seemed to prove Berthold right. All of the five dogs that had received the bole survived the poison, while without it, four of the five other dogs died.

Encouraged by the favorable results from the animal trials, Count Wolfgang von Hohenlohe in Langenburg initiated tests on humans. He had the procedure and the findings documented in a Testimonium, which Berthold put into print in 1583, giving us quite precise information about what happened. A thief who had been sentenced to death, a certain Wendel Thumblardt, ingested in the presence of Count Wolfgang and his nephew Georg Friedrich as well as the entire court half a drachm of mercury sublimate followed by a drachm of terra sigillata. This allegedly took place at the express wish of the man, who had been promised pardon by the count should he survive. The count's court physician Georg Pistorius and the apothecary Johannes Lutzen stayed with Thumblardt and monitored his condition. According to their account, Thumblardt developed severe symptoms after ingesting the poison, yet he survived. ${ }^{147}$

From today's perspective, these trials, even if some of the subjects came away with their lives, darkly recall the inhuman experiments in Nazi concentration camps. By all appearances, however, the physicians - and this is true of Handsch as well - did not believe they were doing anything wrong. Even Michael Boudewijns, who was strongly influenced by Catholic theology, did not categorically reject such trials in his Ventilabrum medico-theologicum, ${ }^{148}$ and, if Mattioli's account is accurate, the pope himself was behind one of the trials. As

145 Cod. 11205 , fol. 530r.

146 Letter from Andreas Berthold to the collegium medicum in Basel, 26 December 1579 (www. aerztebriefe.de/id/00001987, A. Döll/T. Walter).

147 Berthold, Terrae sigillatae (1583); Berthold, Compendium (1589); Berthold, Nützlicher unnd nothwendiger Bericht (1597).

148 Boudewijns, Ventilabrum medico-theologicum (1666). 
is so often the case in the history of ethical norms in medicine, the standards accepted and used to assess and judge moral behavior have changed profoundly. For one thing, voluntary participation was emphasized, something that agrees with modern ideas to a certain extent. In Handsch's words "The poor person took the poison very willingly indeed". ${ }^{149}$ By participating in the trial, the subject stood to receive a milder punishment, perhaps even a pardon - if things went well. And if he died of the poison, he and his relatives would at least be spared the degrading death at the gallows. Moreover, it was usually emphasized that a trial had been ordained by a ruler or at least explicitly endorsed by one. In other words, from the perspective of the period, these people had already forfeited their lives. No one at the time seriously contested the ruler's right to punish criminals with death for their crimes. Their lives were totally in his hands. And finally, not least of all, the trials served the common good - as was pointed out again and again. ${ }^{150}$ For this reason, Johann Heinrich Meibom understood them to be in harmony with the Hippocratic Oath, which did not, he explained, forbid the physician from giving poison to a person condemned to death to test its effects, or those of an antidote, if this served the goal of being able to help others in the future. ${ }^{151}$

The search for new and more effective remedies was a high priority. For similar reasons, someone like Gabrielle Falloppia, too, had no misgivings about killing a total of nine men with opium, and about acknowledging this publicly, in front of his students. After all, knowledge was gained in these instances about the effects of opium; in fact, the men did not show the symptoms that were to be expected according to Dioscorides. And above all, their perfectly intact corpses were ideal for subsequent dissections which would allow the anatomist to make new discoveries and promote medical knowledge. ${ }^{152}$

On the whole, the number of "test subjects" in the trials named above was very small. And such experiments had no place in the practice of ordinary physicians. But they impressively show how an appreciation had grown in the sixteenth century for controlled empirical observation as a source of reliable knowledge.

149 Cod. 11183, foll. $125 \mathrm{r}-128^{\star} \mathrm{v}$ : "Der arm Mensch nam das Gifft willig und gern”; similarly Paré, Response ([1575], p. 12, "tel poison fut pris par le brigand de bonne volonté”.

150 Letter from Graf Wolf von Hohenlohe, 25 January 1581, published in a Latin translation in Berthold, Terrae sigillatae (1583), no pagination: "utilitatem totius humani generis"; and in an English translation in Berthold, Wonderfull and strange effect (1587), pp. 32-35: "for the commoditie and benefite of all Christendome".

151 Meibom, Hippocratis magni Orkos (1643), pp. 128-130.

152 Cod. 11240, fol. 78r. 


\section{Case Histories: Observation at the Bedside}

The growing significance of empiricism and of personal observation in the medical practice of the sixteenth century also found vivid expression in another field, namely in the rise of medical casuistry. Increasingly, the individual case history entered the stage as a major source of knowledge alongside theoretical discussions and commentary on traditional authoritative texts. The individual case no longer served primarily as an exemplum to illustrate a general theory. Making precise observations about countless cases and noting them down - the symptoms, the external circumstances, possible triggering factors, the genesis and development of the disease, and the course it took under medical treatment - would, it was hoped, result in new knowledge. It would place diagnosis, prognosis and treatment on an ever more solid foundation.

Handsch's extensive notes powerfully illustrate this turn toward casuistic observation at the bedside. In thousands of entries, he documented experiences and insights - his own, and those of others - about the effects of remedies, the significance of certain diagnostic and prognostic signs, and other aspects of medical practice. In addition, he also wrote down entire case histories, summarizing them after the fact, or returning to a case in a number of entries or documenting the various visits in chronological order, as in a practice journal, with almost daily notes. Not infrequently, he complemented his notes as time went on with observations and insights coming from comparable cases, noting them down in the margins or providing cross-references to entries on other patients. In this, he was seeking to arrive in an inductive manner, as we would say today, at general conclusions, for example about the value of a diagnostic or prognostic sign or the use of a medication for a particular disease. ${ }^{153}$

In their sheer magnitude, Handsch's notebooks are unique. But many other physicians seem to have also made it a habit to note down their observations and experiences in medical practice, to document the medical cases they treated. They did this in practice journals and notebooks, as well as in collections of case histories from their own practices, which they extracted from their notes. European archives and libraries today hold a substantial number of such handwritten records, ${ }^{154}$ and this despite the unlikelihood of the survival of this kind of material. Even lecture notes, which would have been taken down by the thousands by students at the time and were of obvious value to other students and physicians, are extant only in

153 Historical overview in Milton, Induction (1987).

154 Stolberg, Medizinische Loci communes (2013) gives references to a range of manuscript sources. 
very limited numbers. There is little doubt then that taking notes on individual patients and cases was common practice among learned physicians.

The turn toward medical casuistry, toward the individual case history, was also reflected in the world of publishing and epistolary exchange. After the first beginnings around 1550, ${ }^{155}$ collections of printed medical observationes, casus, enarrationes, and historiae became an important genre that was widely read and quoted. We do need to make a distinction here. Some of these collections and observations of individual cases belonged first and foremost in the domain of natural history. They concentrated on observationes rarae, that is they dealt with unusual clinical pictures and rare pathological phenomena such as bizarre congenital deformities which readers in all probability would never encounter in their own practice. They reflect the contemporary interest in observing miraculous phenomena and (apparent) deviations from the laws of nature. ${ }^{156}$

Some of the most successful and oft-quoted collections, however, contained cases that might easily be encountered by other physicians in their practices. Prominent here were above all German and Dutch physicians in wealthy mercantile and imperial cities - salaried municipal physicians such as Pieter van Foreest in Alkmaar and Felix Platter in Basel, ${ }^{157}$ as well as, in the seventeenth century, self-employed physicians who had extensive urban practices, such as Tulpius in Amsterdam, Heer in Liège, Hechstetter in Augsburg, and Thoner in Ulm. ${ }^{158}$ These urban physicians saw large numbers of patients over the years, often including many less well-off and poor patients, especially if the physicians were also responsible for providing medical care in hospital. It was therefore possible for them to draw on their personal experience in treating hundreds if not thousands of patients who covered the entire spectrum of known diseases.

Medical case reports have long been of interest to historians. ${ }^{159}$ Starting with the numerous individual case histories that are documented in the Hippocratic Epidemics, they have a millennia-old history. Examining early modern observationes, casus and curationes, more recent historical research has highlighted and

155 Amatus Lusitanus, Curationum (1552); in 1562, Girolamo Cardano, in an unabashed selfaggrandizing manner, published a series of reports about difficult cases he had (allegedly) successfully cured (Cardano, Opera (1562), pp. 118-137) under the heading "De curationibus et praedictionibus admirandis".

156 Daston/Park, Wonders (1998).

157 Valleriola, Observationum (1573); Foreest, Observationum (1603-1606); Platter, Observationum (1614).

158 Tulpius, Observationum (1652); Hechstetter, Rararum observationum (1624); Heer, Observationes (1645); Thoner, Observationum (1649).

159 Temkin, Studien (1929); Laín Entralgo, Historia (1961). 
delineated the different types of published case histories as well as their different functions. ${ }^{160}$ But the focus on printed sources easily obscures the fact that published collections of observationes, casus, and curationes were not the cause but already the consequence of a previous turn toward the individual case and toward empirical observation at the bedside in ordinary medical practice. Decades before the first collections of observationes and curationes went into print, case histories assumed a new importance in physicians' notetaking practices and in university teaching.

Along with the increasing orientation toward empirical knowledge in the study of nature as a whole, several factors were advancing this development more specifically in the field of medicine. With the rise of humanism, in which learned physicians played a very active part, there was a valorization of historia, of the observation and description of individual things and phenomena, over and above the Aristotelian ideal of scientia based in the knowledge of causes. ${ }^{161}$ Some extant medical case histories are even explicitly categorized under the heading "Historia", and Handsch, too, used the term "historia" or rather "hystoria" for both general historical depictions and for specific reports and stories about medical cases, such as a "Hystoria" of a sick matron who was "cured by superstitition". ${ }^{162}$ The parallels between medical case histories and other forms of historical accounts are indeed close at hand. Like other historical events - in the case of wars, the comparison is particularly apt - the origin and development of the individual case of illness could be told as a chronological sequence of events, determined by a multitude of individual circumstances. And just as historical accounts of past events aimed to arrive at possible lessons for future action in similar situations, medical histories offered the hope that through them knowledge could be gained that could be useful when treating similar cases. In fact, they owed their popularity largely to this fact.

A key catalyst and driving force of the medical turn toward the individual case and the practice of writing case reports was by all appearance the clinical, bedside training that emerged in northern Italian universities in the 1530s at the

160 Nutton, Case histories (1991) - I am grateful to Vivian Nutton for letting me read the manuscript of this lecture, which unfortunately was never published; Pomata, Praxis historialis (2005); Stolberg, Formen (2007); Pomata, Sharing cases (2010); Pomata, Observation rising (2011); Pomata, Word (2011); these papers also offer extensive bibliographies of printed editions of curationes and observationes.

161 Pomata, Praxis historialis (2005).

162 Cod. 11240, fol. 104r: "Hystoria de matrona aegrota, quae per superstitionem curata [fuit]”; further examples are ibid., fol. 74r; Cod. 11205, fol. 204v and fol. 223r; Cod. 11207, fol. 23r, fol. 72r and fol. 199r; Cod. 11210, fol. 199v. 
latest, influencing generations of future physicians, including many who came from north of the Alps. Men such as Giovanni Battista da Monte in Padua and Antonio Musa Brasavola in Ferrara - where Amatus Lusitanus was active, whose curationes were among the earliest printed collections of case histories - were known as first class humanists and experts on the scholarly literature that had survived from antiquity. Their teaching, however, like that of Fracanzano in Padua and Elideo Padovani in Bologna, for example, focused on the individual case. In the collegia, the public discussions of cases in front of the student body, as held in Padua, and at the bedside, budding physicians learned how to draw conclusions from their observations of sick people, and how to apply their general, theoretical knowledge to individual cases of illness in a manner that was methodologically stringent, making the search for the internal and external causes of the disease their starting point. ${ }^{163}$ Significantly, the first handwritten records of medical case reports from this period that have survived were penned by students, by prospective physicians, that is, rather than by experienced practitioners. The collection of case histories from the practice of Musa Brasavola and other medical professors in Ferrara, which I have cited several times, can be dated to around 1545 at the latest. ${ }^{164}$ And the earliest known example of a collection of case histories that are explicitly characterized as observationes - which in printed collections later on was to become the most common term - is yet something else that originates with Georg Handsch. Under the heading "Observationes ex praxi doctorum Patavinorum”, he filled approximately forty pages in 1551-52 with notes about cases he had seen with Trincavella and other professors. ${ }^{165}$ In the same notebook, he included detailed descriptions of seven cases of illness he encountered in Vicenza with Comes de Monte late in the summer of 1552. Among the headings used here we find, for example, "Tercia observatio de hydrope ex retentis menstruis", about a dropsical peasant woman, and "Quinta observatio de febre interpollata remedioque post purgationem febrem fugante”, about the successful treatment of a febrile woman. $^{166}$

163 Bylebyl, The manifest and the hidden (2004).

164 Biblioteca Ariostea, Ferrara, Collezione Antonelli, Ms. 531; on the date see Part I, note 251. 165 Cod. 11238, foll. 95r-114v; it is not certain that the heading refers to the entries until fol. 114v; these pages are all devoted to such individual case histories, however. A similar heading, "Observationes in praxi medica apud Bellicatum, Helidaeum, Montanum et alios", is found on the first page of one of Johannes Brünsterer's student notebooks. He studied in Padua in the late 1540s already but the heading was probably added later only by Johannes Hesse, who married Brünsterer's widow, in 1555 (on Brünsterer see Stolberg, Teaching anatomy (2018), p. 76, note 10).

166 Cod. 11238, foll. 115r-118v and foll. 70r-74v; the heading of another, shorter passage in this notebook (ibid., foll. 124v-125v) uses the corresponding verb "observare": "Ex praxi D. Comitis de Monte observata". 


\section{Self-Observation: The Physician's Body as a Source of Knowledge}

Not only in Handsch's student notes but also in his notes from his working life as a physician, much attention is devoted to individual cases of illness and observations of specific patients. But it is also striking how often he included notes about his own personal, physical condition and illnesses. He described himself as not particularly robust. He had a tendency to faint, though he had never actually collapsed. ${ }^{167}$ And again and again, he depicted his own experiences with illness. He suffered from fevers a number of times and in his later years he was plagued by stones.

Handsch did not limit himself to simply depicting or describing his complaints. He used his observations of his own body to arrive at general conclusions. Feeling his own pulse, for example, showed him that the pulse before a febrile attack was "hidden" ("occultatus"). ${ }^{168}$ This insight helped him predict the onset of febrile attacks in patients and to impress these patients and their relatives with an exact prognosis and diagnosis. Once, when Handsch believed he was suffering from an obstruction of the spleen, he found a sandy, reddish, soft sediment in his urine, which turned to paste when rubbed between the fingers. He interpreted this as an excreted humor that had been overheated in the liver and could not flow into the spleen due to the obstruction. The examination of his own urine thus provided him with evidence that sandy urine did not always indicate stone disease. ${ }^{169}$ Even Handsch's occasional notes about masturbation take their meaning from this epistemic practice. They are among the earliest known ego-documents on the subject and are thus of interest to historians of sexuality as well. The note-taking here did not serve as an outlet for confession or a means of self-scrutiny, as we sometimes find in later ego-documents. The entries were short, factual, and free of value judgments. They dealt primarily with the consistency of the semen and with the consequences of semen loss to his health and body. ${ }^{170}$

Handsch was not alone in this habit of careful self-observation. Other physicians, too, documented their own illnesses in detail and in a style consistent with the observationes physicians penned about their patients. Much like Handsch, Andrea Gallo used his observations of his own body and urine to counter Mattioli

167 Cod. 11207 , fol. $29 \mathrm{v}$.

168 Cod. 11205, fol. 69v, "ut in me cognovi”.

169 Cod. 11210, fol. $92 \mathrm{v}$.

170 Cod. 11183, fol. 434v and fol. 459v; Cod. 11205, fol. 74v, fol. 81r, fol. 193r, fol. 218r and fol. $513 r$ 
when the latter concluded from a patient's red urine that he was suffering from a fever. Strongly colored, red urine was considered to be a sign of excessive heat in the body, but Gallo knew from his own experience that this sign was deceptive. He explained that his own urine was sometimes red when he was not suffering from a fever. ${ }^{171}$ And not in a journal, but as part of his collection of other medical cases, Bartholmäus Carrichter gave an account under the heading "pro mea persona", describing the hemoptysis, intense bowel complaints, tertian fever, dizziness, and trembling he developed after attending a banquet at an abbot's in 1558. The abbot had first served him light, but then very strong wine. Carrichter's description of the therapy and the course of his illness is detailed. ${ }^{172}$ Girolamo Cardano told of how he first freed himself, and then many other patients, from an excessive flow of urine, while the patients in the hands of other physicians died. ${ }^{173}$ Martin Ruland described the intense bleeding from hemorrhoids that plagued him for many days, even months, at a time. He felt very weakened from the great loss of blood, inasmuch as the blood that was flowing was not black and thick as was common in such cases, but was red, that is, natural blood. He treated his complaints with a small satchel of red cloth containing crushed acorns or oak leaves which had been cooked in strong vinegar. ${ }^{174}$

For his part, Caspar Weckerlin in the early seventeenth century added to his own handwritten "Observationes" a detailed depiction of his own "hypochondriacal" complaints, that is symptoms that were located in the upper abdomen. He had been suffering from asthma or shortness of breath for almost four years. It was worse when he lay on his left side, and he was experiencing pain. He was plagued by intense coughing, especially when reclining, and was forced to stand up. His face was pale, his appetite poor, and he had noticeably lost weight. In the evening, he felt a glowing heat. He salivated profusely and often needed to vomit, especially after drinking wine. Not only this, but for a year he had also been experiencing a sad mood, had been sleeping poorly and had a strong rumbling in his stomach. Added to this was a heavy head and catarrh. He suspected apepsia, an insufficient digestion of food in the stomach, and the development of burnt, black-bilious blood in the liver, which was obstructing it. ${ }^{175}$

Medical notes of this kind about a physician's own body and its diseases are not fundamentally different from those about a physician's patients. In many respects, the physician's own body fulfilled the same function as a source of

171 Cod. 11207, fol. 151v.

172 National Library of Medicine, Bethesda, Ms. E63, fol. 180v.

173 Cardano, Opera (1562), p. 129.

174 Ruland, Curationum (1578), p. 16.

175 Det Kongelige Bibliotek, Copenhagen, Ms. Gl. kongl. S. 4º 1694, fol. 63r, 29 July 1616. 
empirical medical knowledge. It became an object which the physician met with the same distancing, knowledge-seeking attitude as he did when he encountered the bodies of patients. But there is an important difference. When working with patients, physicians had to rely on what patients told them, and could only hope that they described their physical sensations correctly. But physicians believed themselves to be far better trained in recognizing even subtle signs and physical changes which the layperson might miss or consider irrelevant. Thus, to physicians' minds, their own bodies were a source of knowledge that was much more dependable, and could help them better understand their patients' bodies. What Christopher Lawrence found for the natural philosophers in the seventeenth century, was equally true for many Renaissance physicians already: they "regarded themselves as highly reliable reporters of their own sensations and, for this reason, acutely perceptive of goings-on in other bodies". ${ }^{176}$

The prominent place of the physician's own body in Handsch's notes and in those written by other sixteenth-century physicians thus substantiates for medicine the findings of Werner Kutschmann's study on the role of the perception of the naturalist's own body in premodern science. According to Kutschmann, the human body during the Renaissance was "still a measuring stick and a model for 'natural' knowledge". It was only in later times, "in the course of the development of methodologically-constituted experimental science (which was proficient in the use of instruments and technology)" that the body was "displaced from its leitmotif function and faded out". ${ }^{177}$

\section{Post-mortems}

A further field in which the growing significance of empirical approaches in learned medicine made itself distinctly felt and was expressed with particular clarity was the growing practice of post-mortems, that is the dissection of the bodies of deceased patients (Fig. 11). Until very recently, historical research greatly underestimated the prevalence and relevance of post-mortem findings in Renaissance medicine. Works on the history of pathological anatomy have placed great emphasis on the autopsy reports that appeared here and there in Antonio Benivieni's De abditis non nullis ac mirandis morborum et sanationum causis of $1507 .{ }^{178}$

176 Lawrence, Medical minds (1998), p. 166.

177 Kutschmann, Naturwissenschaftler (1986), cit. p. 15; summary of his major arguments in Kutschmann, Naturwissenschaftler (1991); see also Shapin/Lawrence, Science incarnate (1998), esp. the editors' introduction (pp. 1-19).

178 Benivieni, De abditis (1994). 
Benivieni's work and Théophile Bonnet's Sepulchretum sive anatomia practica, ex cadaveribus morbo denatis of 1679 are today considered classics of medical literature. ${ }^{179}$ In their analysis of these works historians have largely focused on the findings that hold up in the eyes of modern medicine, however. This narrow focus has eclipsed the extent to which post-mortems were practiced on an everyday basis, within and outside the academic context, and the relevance that learned physicians attached to autopsy findings as early as the sixteenth century. ${ }^{180}$

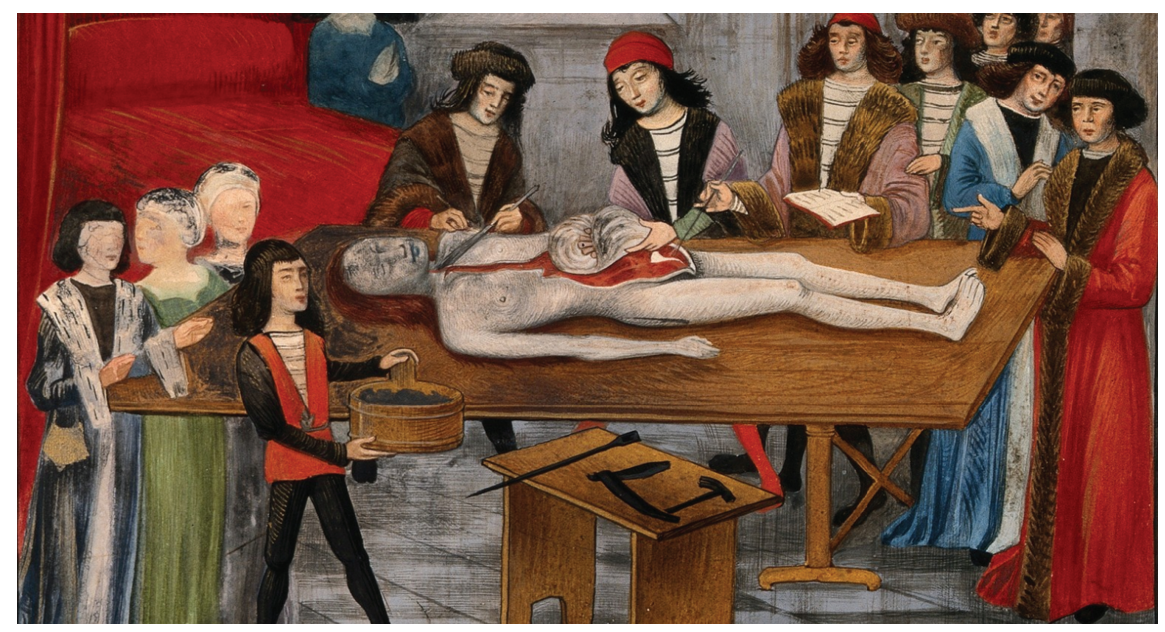

Fig. 11: Unknown artist, Guy de Chauliac performing a dissection, gouache after a $15^{\text {th }}$-century illuminated manuscript, Wellcome Collection, London.

Already a look at the printed medical sources shows quite well that post-mortem findings came to be widely appreciated, not only in Italy but also north of the Alps. ${ }^{181}$ In the case histories of Jean Fernel (1497-1558), for example, of Pieter van Foreest (1521-1597), or Volcher Coiter (1534-1576) there are multiple accounts

179 Bonnet, Sepulchretum (1679).

180 The major exception is an important, seminal study of post-mortem reports from the sixteenth and seventeenth centuries by Nancy Siraisi (Siraisi, Segni (2001)). Siraisi doubts the value of these autopsies, however, and seems to underestimate their epistemic potential and the importance they had in the eyes of contemporary physicians as a source of new knowledge about the body and its diseases. For a study of the interpretation of post-mortem findings in sixteenth- and early seventeenth-century medicine and their relevance for medical practice see Stolberg, Post-mortems (2017).

181 In England, autopsies on deceased patients seem to have been performed less commonly, however (Wear, Knowledge (2000), p. 148). 
of the changes that were found when the bodies of those who had perished of their disease were opened post mortem. ${ }^{182}$ Other authors at least wove the findings of individual autopsies into their published observations ${ }^{183}$ or they collected them in a chapter specially devoted to the subject. ${ }^{184}$ Around 1600 , even an ordinary municipal physician like Jean Chifflet in Besançon was able to supplement his sixty medical observationes with the findings of approximately two dozen autopsies. ${ }^{185}$ Insights were also gained when the bodies of princes were opened for the purpose of embalming or to rule out a possible poisoning. ${ }^{186}$

Without a doubt, reservations about dissection were widespread in the population. But some relatives wanted to learn the true cause of death. Chifflet even mentioned the post-mortem of a patient who had explicitly requested it before he died. ${ }^{187}$ And the published post-mortem findings almost certainly represent only the tip of an iceberg. Undoubtedly, numerous autopsies either produced no clear pathological changes worth publishing or these findings were unsuitable to showcase the exceptional diagnostic skill of the author of a printed case history. In their letters, physicians occasionally mentioned autopsies without saying anything more about the results. Even during epidemics, some physicians attempted to come closer to understanding the nature of the pestilence and its causes by opening up bodies, and did so without publishing their findings. ${ }^{188}$

Handsch's personal notes give us a very similar picture. But in addition they give us a good impression of the multitude of sources on which physicians could draw to learn of dissection findings, and they show the significance of

182 Fernel, Universa medicina (1644), collection of consilia, in the Elector the appendix of the separately paginated part De abditis rerum causis, pp. 247-397; Foreest, Observationum (1634); Coiter, Externarum (1573).

183 E.g. Dodoens, Medicinalium observationum (1581), pp. 13f., p. 43, p. 48, pp. 61f., pp. 67-69, pp. 105f., and p. 123; Sassonia, Pantheum (1603), p. 161; Brasavola, In octo libros aphorismorum (1541); Houllier, De morborum (1567), p. 60, Trincavella, De ratione (1575), p. 352; Boscius, De lapidibus (1580), fol. A3r-v, citing Falloppia and Johannes Pfeil, a personal physician of Moritz of Saxony Donati, De medica historia (1588), foll. 264r-267v.

184 Solenander, Consiliorum medicinalium (1609), p. 493.

185 Chifflet, Singulares observationes (1612); as far as the dates are indicated, Chifflet assembled most of these observationes in the 1590s.

186 See, e.g., the letter from Nikolaus Kistner to Johannes Posthius, 24 June 1574, in which he reported about the dissection of the deceased King Charles IX of France, in which massive changes in one of the pulmonary lobes were found but no evidence of poisoning (Kistner, Opuscula (1611), pp. 991-993, www.aerztebriefe.de/id/00013774, C. Hauck).

187 Chifflet, Singulares Observationes (1612), fol. 32v, "viventis iussu".

188 Thus Johannes Dryander (1500-1560), in 1547 wrote to Graf Wolrad von Waldeck even about several dissections he had performed on victims of the current "pestilential fever" (Wolff, Kartographen (1990), pp. 8f; www.aerztebriefe.de/id/00025350, U. Schlegelmilch). 
autopsies as an essential foundation and an important corrective in medical practice. Numerous entries go back to Handsch's university days. The professors in Padua repeatedly told students about the observations they had made when dissecting the bodies of deceased patients. Bellocati, for example, told his students about a dropsical patient in whose liver blisters or cysts had formed. ${ }^{189}$ And Handsch heard from Falloppia that when he cut open the corpse of a patient who had died of pleurisy, he saw that an apostema, that is a local accumulation of morbid matter or pus, had formed, and that the pleura, usually so delicate and thin, had grown two finger-widths thick. Falloppia added that similar changes could sometimes be observed with the meninges. Falloppia was not prepared to believe that the pus from such an encapsulated apostema could make its way into the lungs and be coughed up, as other physicians claimed. But later he had opened up two patients whose entire chest cavities were filled with pus while the pleurae were completely intact. He concluded that the morbid matter could evidently penetrate the pleura in a miraculous, hidden manner and find its way to the lungs. ${ }^{190}$ Falloppia also told his students about his postmortem findings in patients who had suffered from stone disease: the stone was always in the renal pelvis and never in the substance of the kidney. ${ }^{191}$

In his years as a practitioner, Handsch repeatedly noted down autopsy findings. Some of them were relayed to him by others. Extraordinary findings were widely circulated, it appears. For example, Handsch wrote down the pathological changes that had come to light during the autopsy of the body of Emperor Ferdinand, who after an illness lasting ten months - the diagnosis was catarrh and hectic fever - was so emaciated that he was almost a skeleton and could no longer stand. The physicians not only found a large quantity of sand in the kidneys, but also an indurated, dried-out pulmonary lobe that had become attached to the spine. ${ }^{192}$ From a history of Poland, written by an unnamed physician, Handsch learned about how King George had suffered from extremely swollen feet, a typical symptom of dropsy, which at the time was generally traced to a damaged liver. When his abdominal cavity was "disemboweled" ("exenteratus est"), the liver proved to be spoiled ("corruptum") and in the gall bladder there was a stone the size of a pigeon egg. ${ }^{193}$

189 Cod. 11183, fol. 22r.

190 Cod. 11210, fol. $14 \mathrm{r}$.

191 Ibid., fol. 4v.

192 Cod. 11183, fol. 196v; in the light of such extensive pulmonary changes, modern physicians would suspect above all pulmonary tuberculosis or perhaps a carcinoma. The Emperor's corpse was embalmed afterwards.

193 Cod. 11205, fol. 323v. 
In the above-mentioned cases, the autopsy findings matched the clinical picture and confirmed the physicians' suspicions. But not uncommonly, unexpected findings reminded physicians that they had to be careful with their diagnoses and prognoses, and were thus particularly valuable for future practice. As a cautionary example that might help him avoid public humiliation, Handsch noted down the historia of an Augsburg cardinal who died in Rome while in the intensive care of several physicians. The physicians had diagnosed a stomach disease and had given him numerous medicines which caused him to vomit many times and with such violence that a vein burst. The autopsy, however, revealed that there were no pathological changes in the stomach whatsoever. Instead the cardinal had a large kidney stone. The treatment had been completely wrong. Handsch concluded his entry with a reference to the son of Lorenzo de' Medici who, after the death of his father, ordered that his father's physician be thrown into a well. ${ }^{194}$

Handsch sometimes also received post-mortem reports from his mentors and colleagues in Prague. Gallo told him about a dissection which confirmed that the woman in question had an apostema of the liver, as the physicians had suspected. ${ }^{195}$ From Mattioli he heard that cancer was sometimes discovered in the body on autopsy. ${ }^{196}$ This was an important insight because, as we have seen, in the vast majority of cases, cancer could only be diagnosed in living patients because - as with breast cancer - it could be felt through the skin or if the skin itself was affected, or because - as with uterine cancer - cancerous matter was discharged to the outside of the body.

It appears that Handsch himself never performed a dissection, yet in his immediate environment, especially during his time at the Ambras court, he witnessed the dissection of deceased patients multiple times. A female patient in the gynaeceum, for example, suffered from dropsy when she was alive. She had felt pain when pressure was applied to the area above her liver. And indeed, the autopsy showed that her liver was enlarged and indurated. It had a rough surface and two pea-sized stones were found in the gall bladder. ${ }^{197}$

Surprises were in store during the autopsy of a man who succumbed to his injuries in Innsbruck. It seems that a horse had kicked him in the abdomen. The man's scrotum was extremely swollen and gangrenous. When the archducal

194 Cod. 11183, fol. 445r.

195 Cod. 11207, fol. 6v.

196 Cod. 11183, fol. 286v.

197 Ibid., fol. 289r; the estimated date results from an entry a few pages earlier (ibid., fol. 286r): "Oeniponti A. 67". The term "gynaeceum" may have referred to the Damenstift in Hall, a kind of school for young ladies from the aristocracy; it was founded in 1567 but opened its doors in 1569 only. 
surgeon Hildebrand dissected the body, a wound about three finger-widths wide was found in the stomach wall, however. Vomiting and other typical signs of a stomach wound - as described by authorities such as Celsus - were missing. It was assumed that matter had flowed from the wounded stomach down to the scrotum. "Much happens in sick people that is not written about", Handsch concluded, adding a "nota bene" in the margin. ${ }^{198}$

In May 1571, Hildebrand also performed a post-mortem in Innsbruck on the body of a young man from Trento who had suffered from a dry cough, shortness of breath, and a heaviness in the chest. In the stomach area, a palpable induration had been found on the left. Based on the palpatory findings, the physicians had suspected an apostema of the stomach, yet the autopsy revealed that the stomach was fully intact. The liver, on the other hand, was very hard and of a leaden color. It did not have its natural shape and pustules had formed on its surface. The gallbladder was swollen. In the chest cavity, there were large quantities of blood and water. The substance of the lungs ("substantia pulmonis") had largely dissolved in the area near the heart; all that remained were a few filaments. ${ }^{199}$

Presumably in the same year, the court surgeon Hildebrand performed another dissection, this time on a heavy drinker who had developed a painful tumor in the area of the lower ribs. From the outside, it felt like a drum. The growth had been opened and within a month close to forty pounds of blood and pus were drained with a cannula, along with small particles of more solid substance that resembled spoiled brain matter. The autopsy revealed a greatly enlarged liver that could hardly be held with two hands, including a fist-sized apostema full of stinking pus. The liver was so large that it almost reached the stomach region. Hildebrand explained here that pain or other complaints that seemed to come from the stomach could also have their origins in the liver. ${ }^{200}$

Handsch also gave an account of the autopsy on the body of a ten-year-old boy at the Innsbruck hospital around that time. Two stones that were almost as large as chicken eggs were found in the bladder. ${ }^{201}$ In the case of a tailor, who had suffered from shortness of breath without a cough as well as massive convulsions, and who ultimately succumbed to a colic attack, the intestines proved to be largely intact - the bowels were considered to be an important site or cause of colics. The liver exhibited only blackish particles, but no apostema. It

198 Ibid., fol. 409v; Handsch's notes are in a rough chronological order, suggesting that this post-mortem was performed in 1569.

199 Ibid., fol. 412r.

200 Ibid., fol. 412r

201 Ibid., fol. 445r. 
had, however, become joined with the diaphragm. And above all, parts of the lungs were "corrupted". 202

Handsch's account of the autopsy of Hans Reiter in February 1574 is particularly detailed. The man had not been able to walk for quite some time. A treatment with guaiacum had been of as little benefit as a visit to the healing spring in Partenkirchen. In the end, he suffered from severe respiratory distress, could hardly speak, and ultimately died of asphyxia. Willenbroch, who was the last to treat him, had suspected muscular paralysis in the chest and legs. When Hildebrand opened the body at noon the following day, however, it was the lungs that showed massive changes. Especially the right lung was "corrupted", purulent, and spongy. According to Hildebrand, these pulmonary changes were the cause of the illness. In the renal pelvis, there were also small, hard stones, but not the ulcers which, according to Willenbroch, were the cause of kidney stones. The "nerves" ("nervi"), which ran downward next to the kidneys, were of a "flaccid" ("flaccida") consistency and seemed as if "cooked" ("quasi cocti") - a finding that, even if Handsch did not explicitly say so, would have, in the perspective of the time, confirmed Willenbroch's suspicion of a paralysis of the leg nerves. ${ }^{203}$

With this case, Handsch also wrote down a few technical details regarding how the court surgeon performed the dissection. It is possible that he wanted to acquire the necessary manual skills himself. The face of the dead man was covered, as we see in later depictions of anatomical demonstrations in the Netherlands (cf. Fig. 3). Hildebrand opened the abdomen with two incisions, forming a cross in the umbilical region. Before cutting through a vein, he tied it off to prevent blood from spilling out over the site. ${ }^{204}$

Within about a decade in Innsbruck, in other words, Handsch documented a series of autopsies. Because no comparable sources from this time are available for other towns and courts, it remains unclear whether the tally of dissections in Innsbruck and Ambras was particularly high, perhaps due to the presence of the experienced Hildebrand. On the whole, however, there can be little doubt that autopsies on deceased patients were a far more common occurrence in the sixteenth century than has commonly been assumed.

The main reason why historians have, with few exceptions, paid little attention to the numerous autopsy reports that are extant from as early as the sixteenth century, even in print, and to the appreciation afforded to them by contemporary physicians, is once again a simplistic, indeed flawed understanding of early

202 Ibid., fol. $288 \mathrm{v}$.

203 Ibid., fol. 468r-v.

204 Ibid. 
modern humoral pathology and its complexity and flexibility. If most diseases at the time had truly been attributed to a disrupted balance of the body's four humors, then autopsies would indeed have promised very little insight into the nature of a deceased patient's disease. Obviously, autopsies help uncover pathological changes primarily when a disease causes typical, visible local changes to individual organs or body parts. As we have seen over and again in this book, both physicians and laypeople mainly attributed diseases to pathologically altered humors or other fluid morbid matter, however, which frequently accumulated in certain parts or organs. Accumulations of morbid matter were visible to the naked eye in an autopsy, and as Handsch's descriptions of autopsies go to show, the vast majority of the specific pathological findings described by physicians who performed autopsies on deceased patients could be interpreted in terms of such local deposits.

Sometimes the morbid matter accumulated in a cavity, for example in the lungs or abdominal cavity. And just as it could be found on the outer skin, morbid matter could also collect in small blisters that formed on the surface of an organ. Even more frequently, it could harden in a particular place, build up in it and ultimately obstruct the organ in question. Indurations and enlargements of the liver, the stomach, or the spleen, which the physicians had palpated from the outside when the patient was alive, were now, in an autopsy, plain to see as indurated and enlarged organs. Sometimes the physicians found, as with Hans Reiter, that the organ's substance itself was altered. A lung or the liver might disintegrate and decay. The boundaries between decaying, corrupting organs and local accumulations of corrupting morbid matter were blurred. After all, according to Galenic doctrine, the parenchyma, the very substance of organs, derived from blood and other fluids that permeated the walls of the vessels and solidified.

The most conspicuous and often unmistakable finding - something that takes a prominent position in sixteenth-century autopsy reports and in Handsch's notes as well - was stones. In the living patient, stones or concretions sometimes occurred under the skin, particularly as gouty tophi, or they were excreted as kidney or bladder stones with the urine. Post-mortems showed that such concretions could form in the gallbladder as well, or even in the liver or the lungs. ${ }^{205}$ Their genesis could be explained in two ways. Under the influence of heat, for example in a hot liver, local accumulations of humors could dry out and solidify to such an extent that they turned into sand or stones. Alternatively, just as lime deposits were known to form in the drains of some thermal baths, stones could also come

205 E.g. Leonhard Dold in a letter to Sigismund Schnitzer, [Nürnberg] 1602 (printed in Hornung, Cista medica, p. 441) reported about the dissection of a corpse with stones in the liver and in the left kidney. 
from the tiny particles that had dissolved in the blood or humors, coming together over time as ever larger concretions. As Handsch knew from his discussions with Willenbroch, this explanation nicely corresponded to the Paracelsian doctrine of "tartar". These tiny particles could get caught in the urinary tract, a place where stones tended to form, but they could also form small stones in the liver, which then showed up in the gall bladder. ${ }^{206}$

Even when no pathological finding was present during a dissection, important insights could be gained on occasion, and in some cases the opinion of a traditional authority could be corrected. For example, Handsch gathered from his reading of Galen that with cases of dropsy, the liver was always weak. Willenbroch, however, pointed him to a famous Roman anatomist who, when performing an autopsy on a deceased dropsical patient, discovered a completely clearn and healthy ("purissimum") liver. ${ }^{207}$

Observations made with dead animals could also provide valuable clues about similar pathological changes in humans. Handsch, for example, saw a pig's liver at his father's house whose surface was covered in blisters. The pig had seemed healthy when it was alive, he added. The implication was that blisters of this kind - in animals as in man - could also be harmless in nature. ${ }^{208}$ Handsch also found it worthwhile to note down what he had heard from a butcher about the changes in the liver and lungs of sheep and cows. The butcher explained that these two organs could not only have blisters, which gave off water when they were cut with a knife, but sometimes the organs themselves were rotten or there were accumulations of morbid humors ("apostemata") from which pus ("sanies") issued when opened up. Handsch added here that one could presume that the same thing sometimes happened in humans. ${ }^{209}$ When a peasant woman presented with a greatly distended abdomen, Handsch contradicted the previous diagnosis of a lay healer who suspected an infiltration of the liver with tiny stones (and therefore likely ascites). The empirici simply liked to talk this way, he wrote. He did admit, however, that the liver was sometimes interspersed with stones: he had seen it in the livers of sheep. ${ }^{210}$

206 Cod. 11183, fol. 163v.

207 Ibid., fol. 43r; he changed "corruptione" into "imbecillitate”, i.e. "weakness".

208 Ibid., fol. 22 r.

209 Ibid., fol. 188r: "Sic aliquando in homine credendum."

210 Cod. 11205, fol. 408v. 


\section{Facticity}

As we saw in Part I, medical students and physicians were very well-versed in the humanist notation technique of loci communes. Many of them compiled such loci communes since their youth, collecting quotations from ancient poets and authors, but also documenting their medical collectanea and practical experiences. For the latter, sequential loci communes were particularly suitable. Here, the author did not organize his notes alphabetically or order them as he would structure them in a book. He simply wrote his entries one after another, filling the pages as he went. The result resembled what was called adversaria at the time, a notebook in which entries on the most varied subjects were gathered without any sort of order. ${ }^{211}$ However, the authors still adopted the central, constitutive element of the loci communes method: they assigned keywords or subject headings and used these again for future entries on the same subject. Generally, these keywords or subject headings (capita) were highlighted by writing them larger or in capital letters or by using ink of a different color, or a special marking on the page or in the margin. In this way, entries on a particular subject were easily recognizable as such (cf. Fig. 2) and were quickly identified when the author look for notes on a certain topic. In addition, an index or register could significantly facilitate future searches for different entries that shared the same keyword.

Handsch had good reason to use the sequential loci communes method when he practiced as a physician, as did other physicians and natural historians. ${ }^{212}$ Sequential loci communes offered a very flexible, open tool. They put no restrictions on the choice of new keywords. In medicine and natural history especially, this had great advantages. With the shift towards empirical observation in medicine, the knowledge of specific substances, body parts, pathological phenomena, medicines, objects, and processes gained greater and greater significance. Using the sequential loci communes method, new subject headings could be added ad libitum, for example about a hitherto unknown medicinal plant or a hitherto overlooked anatomical structure.

Notebooks that applied the loci communes principle served as more than memory aids. They also held considerable epistemic potential. Elsewhere I have analyzed these epistemic effects in more detail, as "pluralization”, “categorization", and "decontextualization". 213

211 In his guide to excerpting, Albert Kijper used the term "tumultuarie" (Kijper, Medicinam (1643), p. 265).

212 In the seventeenth century, the Silesian physician Martin Kerger explicitly recommended this approach (Kerger, Methodus (1695))

213 Stolberg, Medizinische Loci communes (2013). 
Pluralization: Using a given keyword to collect passages on a particular subject from the works of different authors, or indeed even of one and the same author, rendered the plurality of observations and opinions immediately visible. Assembling passages on the same issue from different texts in this manner showed virtually at one glance where the cherished ancient authorities contradicted each other or even became entangled in contradictions in their own writings. Awareness of such pluralism and contradictions encouraged the use of ones own senses in order to decide which opinions and observations could be trusted, rather than just relying on the works of authorities.

Categorization: The loci communes method contributed to the reorganization of existing categories and to the creation of new ones. The mere act of choosing a certain locus or keyword and assigning entries from various sources to it could create new knowledge. ${ }^{214}$ This was especially true for medicine and natural philosophy. After all, there was nothing about individual observations and insights that intrinsically implicated the choice of a given locus or heading. Choosing a more or less general heading or category was based on abstraction, and this abstraction could follow very different interests and criteria. In botany and zoology, for instance, different varieties of plants and animals could be construed as separate entities or grouped together as one. This was more than just an intellectual question. For example, the decision could have very specific implications for their therapeutic application: as experience taught, different plants, even if they looked almost identical, often had different specific medicinal properties. A fortiori, the act of assigning individual empirical observations on patients with similar symptoms to disease categories such as "scurvy", “cancer”, "tertian fever", "hysteria", and "dropsy" had significant and far-reaching implications for the understanding and treatments of diseases as such. It reinforced the significance of ontological conceptions of disease, according to which disease entities could be distinguished from each other just like plants or animals.

Decontextualization: with good reason, none other than Francis Bacon (1561-1626), who has been considered by many to be the intellectual father of the often-invoked "scientific revolution" of the seventeenth century, emphatically recommended "the disposition and collocation of that knowledge which we preserve in writing" in the form of a "good digest of common places". ${ }^{215}$ Medical

214 Sharpe (Politics of reading (2000), p. 191)) gives a concise summary of the creative role of the notetaker: "as he selects, paraphrases, arranges, glosses, cross-references and indexes, he performs a very individual reading and interpretation".

215 Bacon, Twoo bookes (1605), p. 106. 
and natural-historical notebooks that follow the loci communes method have an important place in the history of an increasing appreciation of "scientific facts." As Lorraine Daston and others have underlined, the appreciation of "facts" is not a timeless phenomenon. It was only in the course of the early modern period, with the rise of a empirical approaches in science, that "facts" took on a key position. A central characteristic of facts, or more precisely, of their communication in language, with words, is their brevity, and it has sweeping epistemological implications: ideally such brevity reflects the pure, neutral, unconditioned, theoryfree status of "facts". Facts do not follow a prescribed order. Like cards in a deck, they can always be shuffled at random and then rearranged in a different order. Thus, they can serve in new and very different ways as building blocks and as empirical evidence for an unlimited array of arguments, theories, explanatory models, or classifications. ${ }^{216}$

The parallels between these epistemic processes and the nature and function of notebooks following the loci communes method are plain to see. ${ }^{217}$ The characteristic features of the entries were brevity and decontextualization. Passages from larger works and empirical observations were torn from their original context and assigned to individual keywords as the author saw fit. By adapting the use of loci communes, one of the central humanist cultural practices, to suit their own needs, physicians and natural historians helped create and maintain a mental habitus in which factual statements and snippets of knowledge played a key role. Just as school boys and students of philosphy and the liberal arts learned to organize and record short quotes and crucial passages from the works of ancient poets and philosophers according to loci, physicians and natural philosophers began to record short, concise statements and insights from the book of nature, without immediately fitting them into a given classification system that was predetermined by a particular theory.

\footnotetext{
216 Daston, Perché (2001).
}

217 In the words of Daston, Taking notes (2004), p. 445, "the Renaissance humanist practice of excerpting short, pithy quotations from long texts for florilegia and commonplace books bears a close resemblance to the excerpting of short, pithy facts from the continuum of experience"; in her analysis of Jean Bodin's (printed) Universae naturae theatrum Ann Blair, Humanist methods (1992), p. 545, had already argued along similar lines. 


\section{Medicine and the "Scientific Revolution" of the Seventeenth Century}

We have seen, then, how learned Renaissance physicians turned to empiricism, not only in anatomy and botany but also and especially so with respect to questions of medical practice. This striking shift in medical epistemology and methodology found expression in the dedicated search for pathological changes by means of autopsies. It made itself felt in a burgeoning esteem for medical casuistry and for the knowledge gained through induction that came out of this, as opposed to knowledge deduced from general theorems. It was reflected in the development of the loci communes method into an instrument of recording empirical observations. And, in close connection with botany, it became manifest in the effort to verify the effects of medicinal plants and mixtures of drugs, which went so far as to include deadly experiments with persons sentenced to death.

The turn toward empiricism on the part of learned physicians is all the more remarkable as it threatened a central foundation of their professional authority and status. The more the scales tipped from ratio to experientia, the more problematic it became for the physicians to distinguish themselves from the empirici. The shift towards empirical approaches brought them dangerously close to the many healers against whom they unremittingly inveighed, claiming that they only treated patients based on experience, with the implication that they often treated only the symptoms while leaving untouched the true causes of disease, which only the learned "rational" physicians knew how to identify.

The growing esteem for empirical knowledge in medicine over and above book knowledge, as Hal Cook has pointed out, ultimately had far-reaching consequences for the development of the natural sciences as a whole. A striking number of Royal Society members and of the protagonists in the so-called scientific revolution of the seventeenth century on the whole were physicians. ${ }^{218}$ From medicine they brought with them both a pronounced interest in the concrete, specific qualities and faculties of things found in nature, as could only be discerned by precise observation, and with methodological tools that allowed for a systematic verification of these properties. Essential epistemic practices of the scientia nova, as advocated in the early seventeenth century by Francis Bacon (1561-1626), ${ }^{219}$ who has been celebrated as the pioneer of empiricism

218 Cook, Victories (2010); similarly also Ragland, "Making trials” (2017).

219 Bacon, Twoo bookes (1605). 
and father of the scientific revolution, had long been introduced and successfully applied in medical practice. And the idea of utilizing nature and asserting man's dominion over nature was a central feature of medicine as an eminently practical discipline. Tellingly, a medical practitioner, the physician and humanist Girolamo Cardano (1501-1576) put this idea in a nutshell half a century before Bacon: "The study of philosophy as such is a beautiful thing [. . .] but its fruit is the science of natural things which gives rise to the arts, [the science] of propulsion through fire and water, and of the unloading and pulling machines, as well as the knowledge of the qualities of things and causes.” 
